\title{
The Bagouria Barrage 1281 AH / 1864 AD An Archaeological Architectural Study
}

\section{Dr. Badr Abdelaziz Mohammed Badr}

\section{Abstract:}

The Bagouria Barrage is one of the most important establishments that were built in the field of irrigation engineering in the governorate of Menoufia during the reign of Khedive Ismail in 1281 AH/ 1864 AD. The Bagouria Barrage consists of five openings with semi-circular arches. It is noted that the Barrage arches are based on stone pillars separated from each other by openings equipped with iron gates used to open and close the barrage. On the left of the barrage, from the eastern side, there is a lock dedicated to the passage of ships and boats on the Bagouria canal. The Bagouria Barrage contributed to the development of irrigation and agriculture system in Menoufia through supplying the agricultural lands with summer irrigation water and improving the navigation system in the Bagouria Canal. Most notably is the large number of the Nilometers which were established in the vicinity of the Bagouria Barrage for defining the flood level and the necessary balances of the Bagouria Barrage. In addition, the artistic and decorative elements that adorn the Bagouria Barrage are rare because of the nature of the construction that is located in the middle of one of the waterways, The research ends with a table showing the architectural, technical and structural terms used in the research, then the most important results and recommendations followed by a list of the sources and references consulted, and a catalog which includes the illustrative figures and plates used.

\section{Key words:}

The Bagouria Barrage؛ lock؛ piers؛ bedding؛ Iron gates crane ؛weir

- Assistant Professor of Islamic Archeology, Department of Archeology, Faculty of Arts, Port Said University, szabadr@yahoo.com 


\section{Introduction:}

The River Nile is the main source of Egypt's fortune and the nucleus of its life. If the flood came low in a year, it would be a severe drought year, and if the flood increased significantly, it would flood Egypt with its excessive water, so the damage would be greater and the matter severer. As the population of Egypt was increasing and multiplying, it was necessary to carry out a series of water projects to provide irrigation water to cope with the increase in population on the one hand, and to increase the area of agricultural land on the other. The way to do this was to build irrigation barrages ${ }^{(1)}$.

The Menoufia Governorate in the Mohammed Ali Pasha era witnessed significant progress in the irrigation and agriculture system. The irrigation system was transformed from basin irrigation system into permanent irrigation system and the dissemination of summer irrigation which was suitable for irrigation of new crops presented to Egypt by Mohammed Ali, such as cotton and rice. Menoufia is one of the most important governorates that have been abundant in water sources by virtue of its location between the Nile branches at the head of Delta. The governorate is bordered by the Damietta branch on the east side, and the Rosetta branch on the west side, in addition to a network of canals that run through its land, flowing from these two branches. There was a significant interest in irrigation system in Menoufia during the $19^{\text {th }}$ century due to the quality of its land and its close proximity to the capital of Egypt ${ }^{(2)}$.

\footnotetext{
${ }^{(1)}$ Mahmoud El-Gendy, Edafat Gadida fi Dirasat Qanatir Zeftaa Alkubraa Wamulhaqatuha ala Alnil (1319-1320 H/ 1901-1902 AD) Megalat Kuliyat Al'adab b Qena, Aleadad 33, 2010 AD, p. 466.

${ }^{(2)}$ Yasser Al Mahareq, El Menoufia fi Alqarn Althamin Ushar, Silsilat Tarikh Almisryiien, Aladad 184, Alhayya Almisria Aleama 1 Ilkitab, Cairo, 2000 AD, P 220-240.
} 


\section{Frist: Types of Barrages and their architectural composition:}

Barrage is an artificial barrier across a river or estuary to prevent flooding, aid irrigation or navigation, or to generate electricity by tidal power ${ }^{(3)}$. Barrage - in Arabic means "Qantara" (plural: "Qanater") - is a superstructure in the form of arches or a curved embankment built over the river to pass across it, and the water barrage is a canal for transferring water over huge arches, and it is a name given to each arched structure of any kind. Thus, the name "Qantara" is given to any arched structure that embanks the waterways to raise the water level and transfer it to a certain direction after storing. The construction of barrages is the best way to divide the watercourse into several narrow channels by the openings of arches. Thus it is easy to control these openings through opening and closing them by iron gates ${ }^{(4)}$. While the aqueduct is an artificial channel for conveying water, typically in the form of a bridge across a valley or other gap ${ }^{(5)}$.

The barrage is also defined as a brick or stone structure with one or more openings. It consists of foundations across of the waterway on which it is built. It is called Farsh (bedding). On the bedding, pillars are constructed and called Beghal (piers), which are built as a base for arches. The arches were of different forms, under which the water passes and bear the roof of the barrage. The rulers took care of these barrages and built them up to be of strong structure in order to fulfill the purpose for which they were established, and their locations were often places for picnic

\footnotetext{
${ }^{(3)} \mathrm{https}$ ///en.oxforddictionaries.com/definition/barrage

${ }^{(4)}$ Assem Rizk, Moagam Mustalahat Aleamara w Alfunun Alaislamia, Aaktabat Madbuli, Cairo, 2000 AD, P.244.

${ }^{(5)}$ https://en.oxforddictionaries.com/definition/aqueduct
} 
and entertainment, where people gather to see the navigation and the boats crossing the barrage ${ }^{(6)}$.

The types of barrages according to the distribution of the irrigation network are as follows:

1. The first type: Large barrages constructed on rivers such as the Nile River to control the water passing through their openings and to raise the water levels in front of them in an appropriate manner to feed the main and large canals used basically for irrigation of agricultural lands.

2. The second type: Influx barrages, which are constructed at the entrances of the main canals taking from the great barrages, in order to control the water levels behind them according to their design.

3. The third type: Reservoir and distribution barrages, identified by function; this type of barrages is constructed at different distances alongside long and extended canals such as the irrigation canals and the main canals. These barrages are constructed in time of creating new side canals taking from the great canals to control the water levels and regulating the flow of water as well as providing the sub-canals that take their water in front of these barrages.

4. The Fourth type: Estuary barrages which are erected at the end of the main and great canals to control the water in excess of agriculture and irrigation need and transfer it to natural or industrial drainage canals.

5. The fifth type: Division barrages, sometimes also called distribution barrages. They are a multi-purpose barrages set up in one location; their aim is to reserve and distribute water through several barrages that are created in one location.

\footnotetext{
${ }^{(6)}$ Abdelrahman Abdeltawab, Munshatuna Almaeya Abr Alttarikh, Dar Alqalam, Almaktaba Althaqafia, No. 69, Wizarat Althaqafa w Alershad Alqawmii, Cairo, 1963 AD, P. 9.
} 
These are the main types of irrigation barrages used in the Egyptian irrigation system. There is no study of the barrages that does not include any of these types of barrages; despite the multiplicity of types of barrages and the diversity of their names, the main structure and the architectural configuration of all the barrages are the same in all of them except for locks that do not generally exist in the small barrages where the waterway does not allow navigation. In any case, the general body of the barrage consists of beddings, piers, pillars, openings of the arches, surface of the barrage, iron gates and hydraulic equipment such as cranes and operating devices ${ }^{(7)}$.

\section{Second: The role of the Menoufi main canal and the Bagouria canal in the construction of the Bagouria barrage:}

The construction of the Bagouria barrage was associated with the Menoufi main canal (Rayah Al Minoufia) ${ }^{(8)}$, and the Bagouria canal. One of the most important manifestations of this connection is the balance and consistency between the size of the Bagouria barrage and the amount of water flowing from the Menoufi main canal to the Bagouria canal. There is no doubt that the hydraulic design of the Bagouria barrage has been associated with both of waterways that intersect with it; as there is a direct and reciprocal effect between the Bagouria barrage and the Menoufi main canal and the Bagouria canal. The effect of both them on the Bagouria barrage is as follows:-

\section{1- The role of the Menoufi main canal in the construction of the Bagouria barrage:}

The Menoufi main canal extends from El-Qanatir El-Khairiya at the head of the delta, penetrating the Menoufia governorate till it

\footnotetext{
${ }^{(7)}$ Gamal Fathy, Munshaat Alnil Almaeyia b Misr fi Asr Al'usra Aleilawia 1805-1952 AD, Dirasa Atharia Moqarna, Risalat Dukturah, Qism Al'athar Al'iislamia, Kuliyat Al'athar, Gamieat Al Qahera, 1430 AH / 2009 AD, PP. 323 - 324.

${ }^{(8)}$ Rayah: Main canal or large branch, look:-

- Annual reports during the years 1919-1924 on the work of the irrigation department, government press, ministry of public works, Cairo,1923, 1925, 1928, PP. 2 - 4.
} 
connects with the canal of Bahr ${ }^{(9)}$ Shebin El Koum at the AlQarinein barrage and so they become one canal which pours into Burullus Lake. The Shebin canal has taken its waters before digging the Menoufi main canal from the Damietta branch directly at the village of Al-Qarinin ${ }^{(10)}$. Then, Said Pasha, ruler of Egypt, gave order to Fadel Pasha ${ }^{(11)}$, the governor of the Rawdat Al-Bahrain governorate ${ }^{(12)}$ to dig the Menoufi main canal and make it Nilotic until Al Pharaonia village, then Hassan Rasim Pasha ${ }^{(13)}$, Inspector General of Lower Egypt, in the year $1281 \mathrm{H} / 1864$ AD, erected a summer waterway in the Menoufi main canal with a width of $15 \mathrm{~m}$ till the Bagouria canal. In 1282AH / 1865AD, Khedive Ismail, the ruler of Egypt, ordered

\footnotetext{
${ }^{(9)}$ Bahr: An old branch of the Nile used as a canal, look:-

- Annual reports during the years 1919-1924 on the work of the irrigation department, government press, ministry of public works, Cairo,1923, 1925, 1928, PP, 2 - 4.

${ }^{(10)}$ Al-Qurainin is located on the western side of the Damietta branch. It was old village that belonged to Menouf town.

- Mohamed Ramzy, Alqamus Algughrafi 1 Elbilad Almisria min Ahd Qudama' Almisriiyn 'iilaa Sanat 1945 AD, Alhayyat Almisria Aleama 1 Ilkitab, Cairo, 1994 AD, P. 214.

${ }^{(11)}$ Fadel Pasha was born in Cairo in 1830 . He studied with the Egyptian mission in Paris. He was appointed as Minister of Education in 1862, then the Ministry of Finance in 1864 and Justice in 1871. During the reign of his brother Khedive Ismail he was the owner of the right to ascend the Throne. But Ismail confiscated his property and ordered his deportation to Constantinople and died in 1875.

- Amal Muhamad Fahmi, Omara' Al'usrat Almalika Wadawruhim fi Alhaya Almisria, 1882 - 1928AD, Alhayya Almisria Alama 1 ILkattab, 2006 AD, P 27 , 28.

- Ahmad Abdelrhym Mustafaa, Elaqat Misr b Turkia fi Ahd Alkhadiwi Ismaeil, 1863 1879 AD, Dar Almaearif, 1967 AD, PP 58 - 69.

${ }^{(12)}$ Rawdat Al-Bahrain governorate: that name was given to the governorate of Menoufia during the reign of Said Pasha, due to its location between the Damietta and Rosetta branches at the head of the Delta, look:-

- Ali Mubarak, Al khetat Al Tawfiqya Al Gadida 1 Misr wal Qahira w Mudnuha w Biladiha Al Qadima w Alshahira, Part 19, Silsilat Alturath, Cairo, 1432 H / 2008 AD, PP. 23 - 24.

${ }^{(13)}$ Hassan Rasim Pasha was of a Greek origin, He was appointed inspector General of the Lower Egypt, then governor of Damietta from 1861 to 1864 and then governor of Alexandria in the years $1868,1873,1874$ and 1876 . He then assumed the presidency of the Shura Assembly and died in Constantinople in 1883.

- Ahmed Zaki, Kalema Maa Reyad Pasha w Safhaa min Tarikh Masr Alhadeeth, Moasasat Hendawi 1 Eltaleam w Althaqafa, Cairo, 2014, P 26.

- Https://www.shobramiles.yoo7.com

- Https://www.vetogate.com

- https://www.egyptiantalks.org
} 
Ali Pasha Mubarak, head of El-Qanatir El-Khairiya, to re-dig the Menoufi main canal for the second time, starting from the influx of the Menoufi main canal at the head of the Delta to the Bahr Shebin in the village of Al Qarinin. The digging operation was conducted by 80,000 men during a period of 60 days, with capacity of 12 million cubic meters.

In the year $1285 \mathrm{AH} / 1868 \mathrm{AD}$, the Menoufi main canal was widened to its present state, and then it reached 64 meters and made it slopped down $5 \mathrm{~cm}$ in every $1000 \mathrm{~m}$. As a result, all the influxes of irrigation canals that had taken water directly from the Damietta branch in-between El-Qanatir El-Khairiya and the village of El Qarinin in Menoufia were transferred to the Menoufi main canal. The first and most important barrages that were erected at the intersection of the Menoufi main canal with the Bagouria Canal are the Bagouria and the Sersawya barrages ${ }^{(14)}$.

From the foregoing, it is clear that the important role played by the Menoufi main canal in supplying the Bagouria Canal with the Nile water necessary for irrigating the agricultural lands located in the area of the Bagouria Canal in Menoufiya governorate. And this has contributed to transform the irrigation system from basin irrigation to permanent irrigation and flourish the cotton cultivation in Menoufiya during the era of Muhammad Ali Pasha's family.

\section{2- The role of the Bagouria Canal in the construction of the Bagouria Barrage:}

The Bagouria is considered one of the most important canals that irrigated a large surface of the agricultural lands in the Minoufiya and Gharibiya governorates due to the fact that it was $114 \mathrm{~km}$ long ${ }^{(15)}$. The length of the Bagouria Canal in Minoufiya is 67000

\footnotetext{
${ }^{(14)}$ Ali Mubarak, Alkhitat Al tawfiqya Algadida, Part 19, PP. 23, 24.

${ }^{(15)}$ Mukhtar El Qazaz, Munshat Alry w Alsarf Alziraeii fi Shrq Aldilta Khilal Asr 'Usrat Muhamad Ali fi Daw' Mbany Gadida Lam Yasbiq Dirasataha min Qabl, Dirasa Athria
} 
$\mathrm{m}$, and the average width is $25 \mathrm{~m}$. The water level during the flood period is $7 \mathrm{~m}$ high, while during the dryness period reaches $1.5 \mathrm{~m}$. It is an old canal that was Nilotic till $1245 \mathrm{AH} / 1829 \mathrm{AD}$, where it was dug and made a summer canal, and its influx was in the Damietta branch near the village of Bir-Shams ${ }^{(16)}$. This influx has five-arch openings built after completion of the digging of the Bagouria Canal. The openings of its archways include a large arch opening in the center to facilitate the entry and exit of boats. After the Menoufi main canal had been dug up, it intersected with the Bagouria Canal and so the influx of the Bagouria Canal has become from the Menoufi main canal, near the Sersawya barrage, instead of the Damietta. However, because of the increase in the slopping of the Bagouria Canal, most of the waters of the Menoufi main canal were passing through it instead of the Shebin canal, except for a slight amount. Accordingly, in $1309 \mathrm{AH} / 1892 \mathrm{AD}$, orders were issued to increase the water of the Shebin canal and to prevent the silt in the part of the Menoufi main canal that is located between Bagouria Canal and the Qarinin barrage.

It is noteworthy that the Bagouria canal passes through famous areas and villages like Abo-seneta, Bai El Arab, El-Bagour, Shoubra-zangi, Sers El-Layan, Al-Hamul, Sengerg, and Shoubrabas in Monoufiya ${ }^{(17)}$. The old Sersawya barrage was used to

Miemaria, Risalat Majstir, Qism Alathar, Kuliyat Aladab, Gamieat Helwan, 1436 H/ 2015 AD, P. 42.

${ }^{(16)}$ Bir Shams is located on the western side of the Damietta branch. It was old village that belonged to Menouf town.

- Mohamed Ramzy, Alqamus Algughrafi 1 Elbilad Almisria, P. 215.

${ }^{(17)}$ Abu Senita, Bai al-Arab and Shubra Zangi are old villages that belonged to Menouf town until 1813 and now they belong to Al-Bagour town. While Sers El-Leyan, Hamoul and Shubra Bas were old villages belonging to Menouf and all these villages are located on the Bagouria canal.

- Ibn Algayean (Sharf al Deen Yahia), Altohfa Alsaniya b 'Asma' Albilad Almisria, Almaktaba Al'azharia, Cairo 1974 AD, P 110 .

- Ibn Mamati (Al'asaad Ibn Mamati), Qawanin Aldawawin, Maktabat Madbuli, Cairo, 1991 AD , PP. 95, 115, 188. 
increase the water of the Menoufi main canal, and it was made as a supporting for the Bagouria barrage. As a result, the summer water has increased in the Shebin canal and also the governorates of Gharbia and Menoufiya have much benefited from this in increasing the surface of summer agricultural lands, which is the basis of the wealth of people ${ }^{(18)}$.

\section{Third: The descriptive study of the Bagouria Barrage:}

\section{1- Location:}

This Barrage is located on the influx of the Bagouria Canal in the village of Kafr El-Ghunamiya ${ }^{(19)}$, El-Bagour Town, Monoufiya Governorate at the intersection of the Bagouria canal influx with the Menoufi main canal in the village of Kafr El-Ghunamiya in the location where the Menoufi main canal begins to bend eastward in the direction to the Qarinin barrage where it connects with the Shebin canal (Figure no. 1, 2, 3, 4).

\section{2- Founder and date of construction:}

This Barrage was built in the reign of Khedive Isma'il in 1281 $\mathrm{AH} / 1864 \mathrm{AD}^{(20)}$, when Fadil Pasha was the governor of Rawdat Al-Bahrain, and its construction was supervised by Hassan Rasim Pasha, inspector general of Lower Egypt ${ }^{(21)}$.

-Mohamed Ramzy, Alqamus Algughrafi 1 Elbilad Almisria, pp, 213-215.

${ }^{(18)}$ Ali Mubarak, Alkhitat Al Tawfiqya Algadida, Part 19, PP 23, 24.

${ }^{(19)} \mathrm{Kafr}$ El-Ghunamiya is one of the modern villages that belonged to the Bi-Arab village but now all of these villages belong to El Bagour town.

- Mohamed Ramzy, Alqamus Algughrafi 1 Elbilad Almisria, PP. 213-225.

${ }^{(20)}$ Khedive Ismail took over Egypt from 1863 to 1879 . During his rule, he developed Egypt's architecture, economy and administration; he was deposed by the Ottoman Sultan under the pressure of England and France on June 26, 1879. and died in 1895 in Istanbul, look:-

- Abdelrahman Al-Rafi'I, Asr Ismail, Dar Al-Ma'aref, Cairo, 1987. P. 47.

- Ahmed Yousef, Wagihat Alamaer Aldiynia w Almadania b Mudon Alqnah fi Asr Al'usra Alalwia, 1220 - 1372 H / 1805 - 1952 AD, Dirasa Atharia, Risalat Majistir, Qism Alathar,

Kuliyat Aladab, Gamieat Tanta, 1438 H/ 2016 AD, PP. 15 - 16.

${ }^{(21)}$ Ali Mubarak, Alkhitat Al Tawfiqya Algadida, Part 19, P. 23. 


\section{3- Architectural description:}

The Bagouria barrage consists of five semi-circular arch openings, the middle opening is $3.80 \mathrm{~m}$ wide, as it is a large opening intended for the exit and entry of boats ${ }^{(22)}$, the width of the other four openings is 3 meters each, while the height of each opening from the level of the bedding floor to the top of the archway is $8 \mathrm{~m}$. The arches of openings are directly rested on stone piers with a pointed front, starting from the floor level of the bedding to the highest level of the water level. Each pier extends inside the archway of the barrage to $1.70 \mathrm{~m}$, each pier projects from the barrage by a distance of $4 \mathrm{~m}$. (Figure No. 5, 6, 7, 8, 9, 10, 11) (Plate No. 1, 2, 3).

Iron gates were installed on the barrage openings and were fixed from the top in recesses called Dorondat, the gates have iron chains connected and installed on mechanically operated cranes, where the barrage was equipped with 2 diesel mechanical cranes based on iron bars, assigned for the passage of cranes to conduct the balancing process, the opening and closing of the iron gates. It is noted that the iron bars that carry the cranes are based on 6 square pillars of brick, the length of each side is $1 \mathrm{~m}$. and its height is $2.90 \mathrm{~m}$. The barrage was equipped from the front with a small iron viaduct of $1 \mathrm{~m}$. wide and $7 \mathrm{~m}$ long. The viaduct was used by engineers and technicians to follow up the opening and closing of the iron gates and to perform the maintenance and restoration of the barrage. It was also used by sailors during the passage of their boats through the Bagouria lock (Plate No. 4, 5, $6,7,8)$.

In the eastern side of the barrage there is a navigational lock with a width of $8.20 \mathrm{~m}$. and a length of $60 \mathrm{~m}$. and above which is an iron bridge of $7 \mathrm{~m}$. Long and $8.20 \mathrm{~m}$. width, the lock contains a pair of iron gates; one located on the front side of the lock and

${ }^{(22)}$ Ali Mubarak, Alkhitat Al Tawfiqya Algadida, Part 19, P. 23. 
the other pair on the back side were opened and closed during the passage of ships in the lock. Each of the pair gates of the lock has an iron crane, to open and close the gates during the passage of boats, and a set of Manuel tools used in the function of lock (Plate No. 9, 10, 11, 12, 13, 14, 15, 16, 17).

As for the western part of the Bagouria barrage, it contains an arch opening of a barrage at the influx of Bai Al Arab irrigation canal, and the width of this semi-circular arch opening is $3 \mathrm{~m}$. It is built of brick and stone and separated from the Bagouria barrage. This one arch barrage was used for irrigating agricultural land in the villages of Kafr al-Ghunamiya and Bai al-'Arab (Plate No. 18).

To the right side of the Bagouria barrage and on the western side of the Menoufi main canal, there is the Sersawya barrage, which consists of two arch openings, and was built of red brick and Dostour stone ${ }^{(23)}$ in the year $1287 \mathrm{AH} / 1871 \mathrm{AD}^{(24)}$ (Plate No. 19)

The back of the Bagouria barrage is an upper road covered with a layer of asphalt. The width of this road is $8 \mathrm{~m}$. while its length is $116 \mathrm{~m}$. On either side of the road there is a balustrade made of stone and brick, pair of cranes are based on the southern balustrade. The balustrade is decorated with a group of decorative stone mouldings.

\footnotetext{
${ }^{(23)}$ Dostour is a smooth, well-sculpted solid smooth stone that has been used in covering piers and facades of arches, look:-

- Mohamed Fahmy, Aemal Gany Bik Almieamaria 830 AH/ 1427 AD, Dirasa Atharia, Risalat Majstyr, Kuliyat Alathar, Gamieat Alqahira, 1988 AD, P. 164.

- Mohamed Abdelhafeez, Almustalahat Almuemaria fi Wathaeq Ahd Muhamad Ali Wakholafaoh 1805-1879, Altabea Al'uwlaa, Cairo, 2005 AD, P. 69.

${ }^{(24)}$ Ali Mubarak, Alkhitat Al Tawfiqya Algadida, Part 19, P. 23.
} 


\section{Fourth: The Analytical Study of the Bagouria barrage:}

\section{Architectural and constructional units and elements:}

\section{A. Semi-circular arches:}

The semi-circular arches were used in the capping of the arch openings between the piers from the front and the back. The width of the middle opening is $3.80 \mathrm{~m}$. while the four side arch openings are $3 \mathrm{~m}$. wide, and the archivolts has been covered with stones ${ }^{(25)}$. These arches are constructionally functioning in carrying the body of the barrage and the upper road which represents the ceiling of the barrage, as well as in crowning the openings. These arch openings are connected together below the vaults from the front and back, and they represent compact waterways side by side ${ }^{(26)}$.

It is worth noting that the openings of the Bagouria barrage have a semi-circular vault in accordance with the outer shape of arches of the openings. The facades of the arches are similar from the front and back in the Bagouria barrage (Plate No. 3).

\section{B. Piers (central pillars):}

The piers are one of the important architectural elements that are used in the construction of the barrage, which are the central pillars bearing the body of the barrage, the arches and the upper road that is located above the ceiling of the barrage, in addition to the fact that they represent the sides of the water passage openings ${ }^{(27)}$.

The piers were built from red bricks covered with stone. Concerning the shape of them, the front part of the pier came in a pointed shape, and it is the most appropriate to face the currents

\footnotetext{
${ }^{(25)}$ Magdy Elwan, Munshat Alry b Asiout Ibban Asr Muhamad Ali 1220-1372 H / 18051952 AD, Dirasa Atharia, Alnadwa Aleilmia fi Zikraa Alealam Aljalil Al'ustaz Alduktur/ Abdaleziz Salem, Kuliyat Aladab, Gamieat Al'iiskandaria, 2008 AD, P. 283.

${ }^{(26)}$ Mahmoud El Gendy, Edafat Gadida fi Dirasat Qanatir Zeftaa Alkubraa, P. 485.

${ }^{(27)}$ Mahmoud El Gendy, Edafat Gadida fi Dirasat Qanatir Zeftaa Alkubraa, P. 485
} 
of water rushing towards the waterways. The piers start from the lowest floor level of the bedding to the highest level of the water, the length of each pier is $7 \mathrm{~m}$, and they project in front of the openings of the barrage by $4 \mathrm{~m}$.

In fact, the shape of piers, whether in front of the structure or behind it, depends on several key factors during the process of balancing, and the most important of which is to observe the stability and consolidation of the bases of the piers because the pressure of water affects their structural balance ${ }^{(28)}$. Therefore, the piers were made pointed, at the front of the Bagouria barrage, to withstand the pressure of water during its entering into the openings. The piers are also topped with massive square pillars.

\section{Side walls:}

These are supporting walls on both sides of the barrages and navigational locks to strengthen them and they are built of stone, and usually their outer face is vertical, and from the interior they are graded or steep ${ }^{(29)}$.

\section{Ceiling of the barrage:}

The ceiling of the barrage is one of the most important architectural elements of the structure, as it is considered the backbone of the barrage; it also contains the upper road which includes several important architectural elements: the floor of the road, balustrades and the entrances of structure. The ceiling of the barrage is often based on semi-circular vaults of brick above the arch openings, and they are connected horizontally, and covered from the top with stone or black basalt slabs. Sometimes the ceiling of the barrage may have been of reinforced concrete $^{(30)}$.

\footnotetext{
${ }^{(28)}$ Magdy Elwan, Munshat Alry b Asiout Ibban Asr Muhamad Ali, P. 283.

${ }^{(29)}$ Mahmoud El Gendy, Edafat Gadida fi Dirasat Qanatir Zeftaa, P. 486.

${ }^{(30)}$ Gamal Fathy, Munshaat Alnil Almaeyia b Misr fi Asr Al'usra Aleilawia, PP. 327, 328.
} 
Concerning the upper road, which represents the ceiling of the Bagouria barrage, it is about $116 \mathrm{~m}$. long and $8 \mathrm{~m}$. wide. It connects the villages located in the western part of the Bagouria barrage and the other villages located in the eastern side of it. The road is nowadays paved with a layer of asphalt to be used for public transportation. On either side of the barrage there is a balustrade built of brick and stone. (Plate No. 22)

\section{E. Balustrade of the Barrage:}

The side balustrade of the barrage represents an aesthetic aspect that helps in the appearance of the body and the ceiling of the barrage as a structural element of functional and technical importance. Functionally, the balustrade protects the pedestrians and means of transport above the barrage from falling into the water, while technically it takes a vertical shape over the ceiling of the barrage extending from west to east, making the upper road in the form of a street bound on both sides. The balustrade of the Bagouria barrage rises up from the level of the road ground by an appropriate amount, and it is built from the bottom with bricks and covered from the top with stone ${ }^{(31)}$.

The balustrade was used in more than one technical function. In addition to protect against falling into the water, the southern balustrade was used as a channel for the iron bars required for the passage of cranes for the process of opening and closing of iron gates. In the sides of this balustrade, iron links were installed to control and stabilize the iron bars that carry the cranes, in addition to the iron chains that carry the gates (Plate No. 23).

\section{F. The Lock:}

Locks are created in waterways at the sites which have an industrial or natural waterfall, and in areas where water decline is significant. Locks were made to raise the water at a level not more than $4 \mathrm{~m}$. height. When designing the lock, the amount of

${ }^{(31)}$ Gamal Fathy, Munshaat Alnil Almaeyia b Misr fi Asr Al'usra Aleilawia, P. 330. 
silt deposited on the bedding inside the basin and in front of the gates should be considered. It should also be taken into account that the locks are adjacent to the barrage and consist of one building $^{(32)}$.

The lock is considered one of the most important architectural elements of the barrage ${ }^{(33)}$. It is a rectangular water basin made of stone for the passage of ships and boats in both directions, thus, the lock basin mediates two different levels of water ${ }^{(34)}$. The lock basin contains two iron gates in both the front and back sides. The front gate, which overlooks the southern side of the Bagouria barrage, has to be opened so that ships and boats can pass through the front side of the barrage with the high-level of water, and at the same time, the back gate of the lock basin has to be closed, so that the water level in the front side of the lock is equal to the water level inside the lock basin. Then the front gate has to be closed and the back gate has to be opened. Afterwards, the ships or boats can move at the opening of the back gate until they can cross in accordance with the amount of water passing through the lock, in this moment the water level in the lock is then equal to the water level behind. But the opposite occurs when ships or boats pass from the backside of the lock to the front side ${ }^{(35)}$. (Plate No.9, 10, 11)

It is noted that the back walls of the navigation lock have been extended to be suitable for navigation, and to prevent the dangers that may occur during the period of the Nile flood, and the lock consists of the following elements:

\footnotetext{
${ }^{(32)}$ Hussin Sirry, Irrigation Science, Part II, the Government Press, Ministry of Public works, Cairo, 1931 AD, PP. 14, 15.

${ }^{(33)}$ Amen Sami, Molhaq Taqwim Alnil an Al Gusur w Alqanatir w Alkhazzanat ala Alnil w furuh b Misr w Al Suwadan min Fajr Alttarikh ilaa Al'an, Dar Alkutub Almisria, Cairo, 1355 H / 1936 AD, P. 100.

${ }^{(34)}$ Gamal Fathy, Munshaat Alnil Almaeyia b Misr fi Asr Al'usra Aleilawia, P. 331

${ }^{(35)}$ Charl Sakla, Handasat Alriy w Alsarf, Kuliyat Alhandasa, Gamieat Al Mansoura,1991 AD,PP.24-25.
} 


\section{- The iron gates:}

The lock basin contains two large iron gates, one is frontal and the other is back, which are opened and closed by manual tools, so that ships or boats can pass through the lock basin. Therefore, the gates are designed to completely isolate the water exited in the waterway from the lock and water within it, except at the time when the passage of ships and boats takes place during the opening of the lock for navigation. (Plate No.9, 14)

\section{- The manual tools:}

The Bagouria lock contains some manual or hydraulic tools that manage and operate the lock to be suitable for continuous navigation. The lock is operated manually through opening and closing the iron gates by a set of cranes, pedals, Khokha and latches that work for pulling or dragging those gates to carry out the process of opening and closing the lock. The clarification of the scientific concept of these devices is as follows:- (Figure No. 12, 13) (Plate No. 14, 15, 16, 17)

\section{- Cranes:}

Cranes are used to close and open the iron gates from the front side of the barrage to allow water to pass, they also allow the ships and boats to pass in the front and backsides of the lock.

\section{-Pedals:}

Pedals are an iron pipes that rests on supporting pillars used in the balancing process ${ }^{(36)}$.

\footnotetext{
${ }^{(36)}$ Linant de Bellefonds, Notes on the Great Public Works which have been achieved from the earliest ages until 1872, the Government Press, Cairo, 1949 AD, P. 262.
} 


\section{- Khokha:}

Khokha is defined as penetrative between two things ${ }^{(37)}$. This name may have been taken from the fact that they block the boats between the two gates.

\section{- Latches:}

Latches are iron pieces used to close manually the iron gates ${ }^{(38)}$.

\section{- The Lock Bridge:}

It is an iron bridge with a balustrade and an upper iron cover based on 4 iron bars. It is called the bridge of the Bagouria lock. (Plate No.11, 12)

\section{G- The barrage gates:}

The iron gates consist of an iron structure of horizontal solid steel bars in accordance with the width of the arch opening and the size of the side cavities. This kind of gates moves vertically inside hollow ducts formed in the body of piers ${ }^{(39)}$. This type of gates was used in the openings of the Bagouria barrage and the two openings of Al Sersawya barrage, while the opening of Bai Al Arab barrage, adjacent to the Bagouria barrage, is a narrow one with an iron bar gate that closes and opens on it. (Plate No.2, $4,5,18,19)$

\section{H- Drondat (side recesses):}

Drondat are located on both sides of the barrage openings in the front side against water direction. These recesses have latches to which the iron gates are fixed according to the width of the openings. These gates move by massive metal chains connected

\footnotetext{
${ }^{(37)}$ Ibn Manzoor, (Mohamed Ibn Makram), Lesan ELarab, Dar Sader, Beirut, 1414 AH / 1993 AD, PP. 403 - 455.

- Al-Fayrouz Abadi (Magdeldin Mohamed), Alqamus Al Moheet, Bayrut, 1429 H / 2005 AD, Madet Khokh.

${ }^{(38)}$ Ministry of Education, Almaegam Alwasit, Wizarat Altarbia w Altaelim, Cairo, 1960 AD, Madet Mizlag.

${ }^{(39)}$ Gamal Fathy, Munshaat Alnil Almaeyia b Misr fi Asr Al'usra Aleilawia, P. 334.
} 
to mechanically operated cranes, and thus conducting the opening and closing the gates and helping in the balancing process $^{(40)}$. (Plate No. 5)

\section{I- Balancing:}

It is an engineering process that has been considered one of the functional purposes of the barrage and is also known as the water balancing. The function of balancing is to control the water levels and quantities in front of and behind the barrage through the iron gates installed on the openings of the barrage ${ }^{(41)}$.

\section{J- The bedding:}

The bedding is one of the basic structural elements that precede the construction of the barrage as it represents the foundation on which the structure is based. It is a preparation of the site prior to commencing the construction of the barrage units and the various architectural elements ${ }^{(42)}$ The bedding consists of blocks of brick, rubble, stone or concrete in order to strengthen and stabilize the ground for building the barrage and various architectural elements; in addition to the preparation of the front and back area of the barrage to make the flow of water passing through the openings faster than its normal speed, as well as to facilitate the operation of iron gates that close and open the openings of the barrage ${ }^{(43)}$.

\section{K- The Weir:}

It is an industrial structure consisting of stone blocks, rubble and bricks, existed behind the barrage. The weir helps increase the speed of slopping and passing of water. One or more weirs may be made according to the size of the barrage on the waterway and

\footnotetext{
${ }^{(40)}$ Amen Sami, Molhaq Taqwim Alnil, P. 111.

${ }^{(41)}$ Amen Sami, Molhaq Taqwim Alnil, P. 111.

${ }^{(42)}$ Hashim Abdelsalam \& Hassan El Sherbini, 'Aemal Alry f Misr, Wizarat Al'ashghal Eleumumia, Aljuz' Al'awal, Almatbaea Al'amiria, Cairo, 1957 AD, P 108.

${ }^{(43)}$ Magdy Elwan, Munshat Alry b Asiout Ibban Asr Muhamad Ali, P. 290.
} 
the amount of balancing it contains ${ }^{(44)}$. It is noted that the Bagouria barrage contains only one weir. (Plate No. 20, 21)

\section{L- The Cranes:}

The Cranes are used to raise and move the iron gates. They operate through a manual arm in the shape of a wheel, and also it contains a set of pedals, gears and other metal parts ${ }^{(45)}$. The Crane is operated by a technical worker who closes and opens the iron gates from both the front and back sides of the lock to allow the crossing of ships and boats as well as the closing and opening of iron gates in front of the openings (Plate No.6, 14, 15).

\section{$M-$ The entrances to the Bagouria barrage:}

There are two entrances on the upper road of the Bagouria barrage; one is located on the eastern side and the other on the western side of the barrage, in addition to two other entrances on the north side behind the barrage. While stone stairs lead to the southern side, in front of the barrage, and these stairs are located on the western and eastern side of the southern balustrade. All these entrances are simple and have on either side decorative stone mouldings (Plate No. 22, 23, 24, 25).

\section{The artistic and decorative elements of the Bagouria barrage:-}

The artistic and decorative elements used in the Bagouria barrage were characterized by rarity; they were limited to decorative stone mouldings that adorned both sides of the eastern and western entrances of the upper road of the barrage, the lock, the side entrances leading to the front and back of the barrage and stone staircase balustrade in the south-west of the upper road of the Bagouria barrage. This rarity is due to the nature of the

\footnotetext{
${ }^{(44)}$ Magdy Elwan, Munshat Alry b Asiout Ibban Asr Muhamad Ali, P. 291.

${ }^{(45)}$ Zoltan A. Vattai, construction equipment, lifting and transporting, Budapest university of technology and economics, department of construction technology and management, Budapest, 2010, PP. 4-17.
} 
structure as it is a barrage locating on a waterway. (Figure No. 14, 15, 16, 17, 18, 19) (Plate No. 26, 27, 28, 29, 30, 31)

\section{Nilometers of the Bagouria barrage:}

The rulers of Egypt, in the era of Mohammed Ali Pasha's family, were interested in building Nilometers on the barrages in most parts of the country to recognize the level of flood Nile height due to its close relationship with the irrigation and agriculture system. The majority of the Nilometers contain marble scales of a width of $15 \mathrm{~cm}$. and a thickness of $8 \mathrm{~cm}$. It has a ruler slab divided into centimeters written in small, and meters written in large, and on each scale there are signs written with the meter level, the marble scales have to be installed on the side walls in front of and behind the barrage and locks in sites that are easy to read. Also there are stone or iron stairs next to the marble scales so that the water level can be read ${ }^{(46)}$.

It is interesting to note the existence of a group of marble Nilometers in the metric system on the eastern walls in front of and behind the Bagouria barrage and the lock. They are six Nilometers, one of which is located on the eastern wall of the lock from the front side, another three Nilometers are located in the eastern wall behind the lock and the 5th one is located on the eastern wall of weir behind the barrage, and the 6th and last is next to the Al-Sarsawya barrage. These Nilometers contain a marble slab fixed on the walls in a vertical position, and the marble slab is divided into a meter and a centimeter to measure the water level during the balancing and operating the lock. (Figure No. 20, 21) (Plate No. 32, 33, 34, 35, 36)

\section{Building materials used in the Bagouria barrage:}

The building materials used in the construction of the Bagouria barrage included the old components of the building material of brick, stones and Kasroumil (ash-dust), and the modern building

${ }^{(46)}$ Hussin Sirry, Irrigation Science, Part II, PP. 38, 39. 
components which are based on ordinary and reinforced concrete and steel as well as iron and wood. The main types of building materials used in the Bagouria barrage are as follows:-

\section{A- Concrete:}

Two types of concrete were used in the construction of the barrage architectural units and elements. The first is the ordinary concrete, consisting of a mixture of sand, cement and a small stone break, and used in the building of piers and arches. The second type is reinforced concrete used in the construction of bedding in the front and behind the barrage, as well as in the body of bridge and the upper road where some iron bars were placed $^{(47)}$.

The concrete has contributed to strengthening and reinforcing the bedding and making a balance and stability in front of and behind the openings of the arches and in piers as well as the reduction in the water leakage. It is worth mentioning that concrete was used in Europe in $1271 \mathrm{AH} / 1804 \mathrm{AD}$ in civil establishments ${ }^{(48)}$.

\section{B- Stone:}

Stone is one of the most important building materials used in the erection of water constructions because it is characterized by being insoluble in water. Thus, the cased limestone was used in the composition of piers, arch openings and lock walls as well as the bedding (49). Many types of stone, especially limestone, Dostour and rubble, were used in the Bagouria barrage for the casing of arches, facades, piers, supporting sidewalls, navigational lock walls and balustrade of the upper road, and a large part of them was used in the bedding.

\footnotetext{
${ }^{(47)}$ Mahmoud El-Gendy, Edafat Gadida f Dirasat Qanatir Zeftaa Alkubraa, P. 484.

${ }^{(48)}$ Magdy Elwan, Munshat Alry b Asiout Ibban Asr Muhamad Ali, P. 286.

${ }^{(49)}$ Magdy Elwan, Munshat Alry b Asiout Ibban Asr Muhamad Ali, P. 287.
} 


\section{C- Bricks:}

Red brick ${ }^{(50)}$, made in the Alexander Murdoch's factory located nearby, was used in great proportions for the construction of the Bagouria barrage, where it was used in the bodies of the arch openings, the piers, the side walls of the lock, the shoulders and the lower parts of balustrade.

\section{D- The mortar:}

Several types of mortar were used in the construction of the barrages, such as the regular mortar, consisting of lime and sand, used between the stones and in the casing works and the front bedding. Also the water mortar, which is composed of soft lime, sand and grinded red brick, was used to construct the parts covered with water such as bedding and piers. The cement mortar consisted of cement plus sand, was used for the bedding so as to strengthen it against the speed of the current and the rush of water behind the barrage ${ }^{(51)}$.

The Kasromil (Ash-dust), which is a kind of mortar composed of lime, grinded red brick and ash, was used in casing the bodies of arch openings and the lock walls, as this material is considered to be a moisture-proofing, and it prevents water intrusion ${ }^{(52)}$.

The regular mortar, water mortar, cement mortar and Kasromil (Ash-dust) mortar were used in the construction of the Bagouria barrage. There is no doubt that the construction of the Bagouria barrage included many other building materials such as iron used

\footnotetext{
${ }^{(50)}$ The Nile clay and the black mud of the agricultural soil were used in the making of red brick used for the construction works of the barrages, where they were mixed with water and then poured into wooden molds, afterwards these wooden molds would be removed immediately after pouring and then left to dry. After drying, the mud molds were collected to be burnt in special brick factories.

- Gamal Fathy, Munshaat Alnil Almaeyia b Misr fi Asr Al'usra al Alawia, P. 371.

${ }^{(51)}$ Gamal Fathy, Munshaat Alnil Almaeyia b Misr fi Asr Al'usra al Alawia, P. 371.

${ }^{(52)}$ Madiha Hosny, Qanatir Almiah fi Misr min Alasr Altuolunii ilaa Asr Osrat Muhamad Ali Basha, Dirasa Atharia Hadaria, Risalat Majstir, Qism Alathar Alaislamia, Kuliyat Alathar, Gamieat Alqahira, 2004 AD, P. 187.
} 
in the manufacture of iron gates, cranes, and iron chains, as well as wood and other materials.

\section{Functional purposes of the Al-Bagouria barrage:}

The barrages are one of the most important industrial irrigation constructions that have been set up to control, supply and distribute the water of the River Nile through reservation to raise the water levels in front of them or to form industrial ponds for irrigation and agriculture purposes ${ }^{(53)}$.

The barrages are made up of a set of openings equipped with iron gates that control the passage of the water where they are closed and opened as needed, and then the irrigation barrages are built for certain purposes ${ }^{(54)}$.

The Bagouria barrage has played an important role in controlling the water levels in front, as well as, water discharged or passed through the openings according to the reservation and distribution system. The Bagouria barrage also contributes to the supplying of irrigation canals and narrow waterways that branch out from the Bagouria canal with the irrigation water needed to cultivate the lands located nearby, sometimes the Bagouria barrage has had other purposes such as providing drinking water, in addition to navigation.

The other functional purposes of the Bagouria barrage are as follows:

A- The building of new sub-canals taking from the Bagouria canal, in addition to filling the exited sub-canals, side canals and sub-water courses with water to mainstream the permanent irrigation system, as well as paying interest in irrigation and transportation, and improving navigation in the canals connected to Bagouria canal.

${ }^{(53)}$ Abdelazem Saudi, Tarikh Tatawor Alriy fi Misr (1182 - 1914 AD), Alhayya Almisria Aleama 1 Elkitab, Cairo, 2007 AD, P. 176.

${ }^{(54)}$ Mahmoud El Gendy, Edafat Gadida fi Dirasat Qanatir Zeftaa Alkubraa, PP. 467, 468. 
B- Reserving and distributing water through other barrages such as the barrage of Sersawya and the barrage of Bai Al Arab.

C- Regulating of the Nile waters in the Menoufi main canal to provide water needed for summer crops, especially the cotton, as well as the rearrangement of the irrigation system so that each region gains the proportion of water allocated to it on specific times ${ }^{(55)}$.

D- Supplying the areas located in the range of the Bagouria Canal with drinking water, in addition to navigational purposes where the Bagouria barrage includes a lock in the east side, and a large opening in the middle of the barrage to facilitate the crossing of boats ${ }^{(56)}$.

${ }^{(55)}$ Abdelazem Saudi, Tarikh Tatawor Alriy fi Misr, P. 41.

${ }^{(56)}$ Ali Mubarak, Alkhitat Al Aawfiqya Algadida, Part 19, P. 37. 


\section{A table showing the architectural, technical and structural terms used in the research}

\begin{tabular}{|c|c|c|c|}
\hline No. & Term & $\begin{array}{l}\text { Meaning of } \\
\text { the term }\end{array}$ & Explanation of the term \\
\hline 1 & Badala & Pedal & $\begin{array}{l}\text { An iron tube based on pillars used to pass water from } \\
\text { one watercourse to a higher one. }\end{array}$ \\
\hline 2 & Baghla & Pier & $\begin{array}{l}\text { Central pillar bearing the body of the barrage and } \\
\text { arches that coronate it, in addition, it forms the sides of } \\
\text { the openings for passing water. }\end{array}$ \\
\hline 3 & Bahr & Canal & An old branch of the Nile used as a canal \\
\hline 4 & Drond & Recess & $\begin{array}{l}\text { A runway or cavity located on either side of the arch } \\
\text { openings in the front, where the iron gates are fixed } \\
\text { according to the width of the openings. }\end{array}$ \\
\hline 5 & Farsh & Bedding & $\begin{array}{l}\text { The preparation of the site before the construction of } \\
\text { the barrage, and this is done by preparing the bottom } \\
\text { with bricks and stone or concrete to stabilize the } \\
\text { ground on which the barrage is built. }\end{array}$ \\
\hline$\overline{6}$ & Fom & Influx & The start of a waterway, main or branch \\
\hline 7 & Haddar & Weir & $\begin{array}{l}\text { An industrial construction consisting of stone blocks } \\
\text { and bricks, and is built behind the barrage to increase } \\
\text { the speed of the inclination and flow of water. }\end{array}$ \\
\hline 8 & Hawees & Lock & $\begin{array}{l}\text { In Arabic means basin, an industrial navigation } \\
\text { waterway, which is located next to the barrage for the } \\
\text { passage of boats from both sides. }\end{array}$ \\
\hline 9 & Kasromil & Ash - dust & $\begin{array}{l}\text { A kind of mortar composed of lime, red brick, ash and } \\
\text { coal dust after burning it with fire, where it is mixed } \\
\text { and left to brew, and then used in the casing of barrage } \\
\text { openings }\end{array}$ \\
\hline 10 & Khokha & $\begin{array}{c}\text { Manual } \\
\text { tool }\end{array}$ & $\begin{array}{l}\text { It is defined as penetrative between two things. This } \\
\text { name may have been taken from the fact that they } \\
\text { block the boats between the two gates }\end{array}$ \\
\hline 11 & Mizlag & Latch & A piece of iron used to close the iron gates manually. \\
\hline 12 & Mowazna & Balancing & $\begin{array}{l}\text { An engineering process to control the water levels and } \\
\text { quantities in front of and behind the barrage, and the } \\
\text { amount of water passing through the iron gates } \\
\text { installed on the openings. }\end{array}$ \\
\hline
\end{tabular}




\begin{tabular}{|c|c|c|l|}
\hline 13 & Rayah & Main canal & Main canal or large branch. \\
\hline 14 & Shamaa & Metal beg & $\begin{array}{l}\text { A metal peg installed on the side pavement of the lock } \\
\text { used to tie the ropes of boats and ships during stopping } \\
\text { in the lock between the gates. }\end{array}$ \\
\hline $\mathbf{1 5}$ & Winch & Crane & $\begin{array}{l}\text { A machine used to close and open iron gates from the } \\
\text { front of the barrage to allow water passage, and from } \\
\text { the front and backsides of the lock to allow passage of } \\
\text { ships and boats. }\end{array}$ \\
\hline
\end{tabular}




\section{Research Results:-}

1- The Bagouria barrage has contributed to the transformation of the irrigation system in the areas within its scope from seasonal irrigation system into a permanent irrigation system and the provision of irrigation water in the summer. This leads to the flourishing of cotton cultivation in Menoufiya governorate during the era of Mohammed Ali Pasha's family.

2- The construction of the Bagouria barrage was connected with the then nature of the Menoufi main canal and the Bagouria canal. This correlation is reflected in the balance between the size of the Bagouria barrage and the amount of water flowing from the Menoufi main canal to the Bagouria Canal.

3- The Bagouria barrage is considered one of influx barrages as it was built at the intersection of the influx of the Bagouria Canal with the Menoufi main canal.

4-The Bagouria barrage has served as a reservation and distribution barrage through the supply of part of the water to the Sarsawya barrage of and Bai-Al Arab barrage.

5- The Bagouria barrage has facilitated the movement of transport and communication as its ceiling contains an upper road, with balustrade on either side, connected between the villages and areas located in the east and those located in the west.

6- The scarcity of the artistic and decorative elements is explicit in the construction of the Bagouria barrage, as it is confined to some decorative stone mouldings due to the nature of the establishment that mediates a watercourse.

7- The multiplicity of Nilometers, which were established in the Bagouria barrage area, is obvious. This shows the keenness of rulers of the era of Muhammad Ali Pasha's family to know the flood level and make balancing in the vicinity of the Bagouria barrage. 
8- The marble stela which adorns the western wall of the Bagouria lock basin shows the renovation and restoration works that were carried out in the lock of the Bagouria barrage in 1329 $\mathrm{AH} / 1911 \mathrm{AD}$.

\section{Recommendations:}

1- The annexation and registration of the Bagouria barrage as an Islamic monument and the cooperation between the Ministry of Antiquities and the Ministry of Water Resources and Irrigation to work on the restoration of the Bagouria barrage due to its important archaeological, architectural and cultural value.

2- The Ministry of Water Resources and Irrigation should pay more attention to the maintenance of the Bagouria barrage and its lock, to cleaning the area surrounding the barrage and the lock from the front and the back, and to re-activating the lock by maintaining the cranes and the operating tools, and to case the walls of the construction.

3- The Ministry of Water Resources and Irrigation should work on putting an organized plan to remove the existing infringements within the scope of the Bagouria barrage and to disinfect the Bagouria canal . 


\section{Bibliography}

- Abdelazem Saudi, Tarikh Tatawor Alriy fi Misr (1182 - 1914 AD), Alhayya Almisria Aleama 1 Ilkitab, Cairo, 2007 AD.

- Abdelrahman Abdeltawab, Munshatuna Almaeya Abr Alttarikh, Dar Alqalam, Almaktaba Althaqafia, No. 69, Wizarat Althaqafa w Alershad Alqawmii, Cairo, 1963 AD.

- Abdelrahman Al-Rafi', Asr Ismail, Dar Al-Ma'aref, Cairo, 1987.

- Ahmad Mustafaa, Elaqat Misr bi Turkia fi Ahd Alkhadiwi Ismaeil, 1863 - 1879 AD, Dar Almaearif, 1967 AD.

- Ahmed Yousef, Wagihat Alamaer Aldiynia w Almadania b Mudon Alqnah fi Asr Al'usra Alalwia, 1220 - 1372 H / 1805 - 1952 AD, Dirasa Atharia, Risalat Majistir, Qism Alathar, Kuliyat Aladab, Gamieat Tanta, 1438 H/ 2016 AD.

- Ahmed Zaki, Kalema Maa Reyad Pasha w Safhaa min Tarikh Masr Alhadeeth, Moasasat Hendawi 1 Eltaleam w Althaqafa, Cairo, 2014.

- Al-Fayrouz Abadi (Magdeldin Mohamed), Alqamus Al Moheet, Bayrut, 1429 H / 2005 AD.

- Ali Mubarak, Al khetat Al Tawfiqya Al Gadida 1 Misr wal Qahira w Mudnuha w Biladiha Al Qadima w Alshahira, Silsilat Alturath, Part 19, Cairo, 1432 H / 2008 AD.

- Amal Fahami, Omara' Al'usrat Almalikat Wadawruhim fi Alhaya Almisria, 1882 - 1928, Alhayya Almisria Alama li Lkattab, 2006 AD

- Amen Sami, Molhaq Taqwim Alnil an Al Gusur w Alqanatir w Alkhazzanat ala Alnil Wafuruh b Misr w Al Suwadan min Fajr Alttarikh ilaa Al'an, Dar Alkutub Almisria, Cairo, 1355 H / 1936 AM.

- Assem Rizk, Moagam Mustalahat Aleamara w Alfunun Alaislamia, Maktabat Madbuli, Cairo, 2000 AD.

- Charl Sakla, Handasat Alriy Walsarf, Kuliyat Alhandasa, Gamieat Al Mansoura, 1991 AD.

- Gamal Fathy, Munshaat Alnil Almaeyia b Misr fi Asr Al'usra Alalawia 1805-1952 AD, Dirasa Atharia Moqarna, Risalat Dukturah, Qism Al'athar Al'iislamia, Kuliyat Al'athar, Gamieat Al Qahera, $1430 \mathrm{AH} / 2009 \mathrm{AD}$.

- Hashem Abdelsalam \& Hassan El Sherbini, 'Aemal Alry fi Misr, Wizarat Al'ashghal Aleumumia, Aljuz' Al'awal, Almatbaea Al'amiria, Cairo, 1957 AD.

- https://en.oxforddictionaries.com/definition/barrage

- https://www.egyptiantalks.org

- Https://www.shobramiles.yoo7.com 
- Https://www.vetogate.com

- Hussin Sirry, Irrigation Science, Part II, the Government Press, Ministry of Public works, Cairo, 1931AD.

- Ibn Algayean (Sharf al Deen Yahia), Altohfa Alsaniya b 'Asma' Albilad Almisria, Almaktaba Al'azharia, Cairo 1974 AD.

- Ibn Mamati (Al'asaad Ibn Mamati), Qawanin Aldawawin, Maktabat Madbuli, Cairo, 1991 AD.

- Ibn Manzoor (Mohamed Ibn Makram), Lesan ELarab, Dar Sader, Beirut, 1414 AH / 1993 AD.

- Linant de Bellefonds, Notes on the Great Public Works which have been achieved from the earliest ages until 1872, the Government Press, Cairo, 1949 AD.

- Madiha Hosny, Qanatir Almiah fi Misr min Alasr Altuolunii 'iilaa Asr Usrat Muhamad Ali Basha, Dirasa Atharia Hadaria, Risalat Majstir, Qism Alathar Alaislamia, Kuliyat Alathar, Gamieat Alqahira, 2004 AD.

- Magdy Elwan, Munshat Alry bi 'Asyut 'Ibban Asr Muhamad Ali 1220-1372 H / 1805-1952 AD, Dirasa Atharia, Alnadwa Aleilmia fi Zikraa Alealam Aljalil Al'ustaz Alduktur/ Abdaleziz Salm, Kuliyat Aladab, Gamieat Al'iiskandaria, 2008 AD.

- Mahmoud El-Gendy, Edafat Gadida fi Dirasat Qanatir Zafataa Alkubraa Wamulhaqatuha Ala Alnil (1319-1320 H/ 1901-1902 AD) Majalat Kuliyat Al'adab b Qena, Aleadad 33, 2010 AD.

- Ministry of Education, Almaegam Alwasit, Wizarat Altarbia w Altaelim, Cairo, 1960 AD.

- Ministry of public works, Annual reports during the years 19191924 on the work of the irregation department, government press, Ministry of public works, Cairo, 1923, 1925, 1928.

- Ministry of Public Works, Canals Sources, Bulletin No. 3, Cairo, 1959 AD.

- Mohamed Abdelhafeez, Almustalahat Almuemaria fi Wathaeq Ahd Muhamad Ali Wekholafaoh 1805-1879, Altabea Al'uwlaa, Cairo, 2005 AD.

- Mohamed Fahmy, 'Aemal Gany Bik Almieamaria 830 AH/ 1427 AD, Dirasa Atharia, Risalat Majstyr, Kuliyat Alathar, Gamieat Alqahira, 1988 AD.

- Mohamed Ramzy, Alqamus Algughrafi 1 Ilbilad Almisria min Ahd Qudamaa' Almisriiyn 'iilaa Sanat 1945 AD, Alhayyat Almisria Alama 1 Ilkitab, Cairo, 1994 AD. 
- Mukhtar El Qazaz, Munshat Alry Walsarf Alziraeii fi Sharq Aldilta Khilal Asr 'Usrat Muhamad Ali fi Daw' Mbany Gadida lam Yasbiq Dirasataha min Qabl, Dirasa 'Athria Miemaria, Risalat Majstir, Qism Alathar, Kuliyat Aladab, Gamieat Helwan, 1436 H/ 2015 AD.

- Yasser Al Mahareq, El Menoufia fi Alqarn Althamin Ushar, Silsilat Tarikh Almisryiien, Aladad 184, Alhayya Almisria Aleama 1 Ilkitab, Cairo, 2000 AD.

- Zoltan A. Vattai, construction equipment, lifting and transporting, Budapest university of technology and economics, department of construction technology and management, Budapest, 2010 


\section{Maps, Figures and Plates Catalogue}

\section{Frist: Maps and Figures:-}

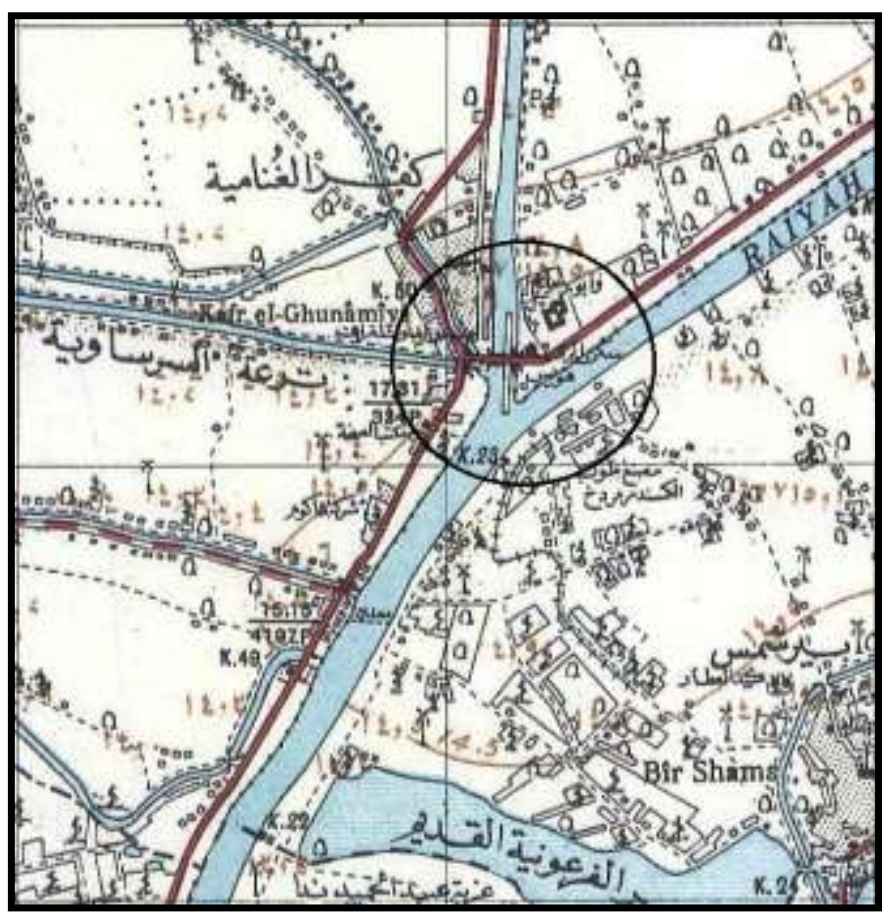

Figure 1

A map showing the location of the Bagouria barrage at the intersection of the Bagouria canal with the Minoufi Main Canal . (The Egyptian Survey Authority)

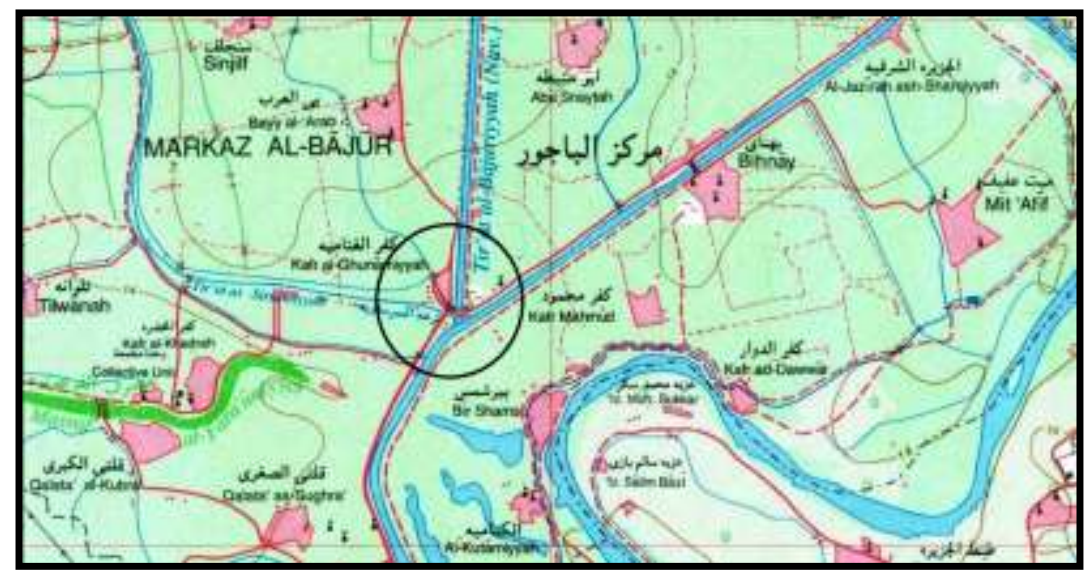

Figure 2

A map showing the location of the Bagouria barrage at the intersection of the Bagouria canal with the Minoufi Main Canal. (The Egyptian Survey Authority) 


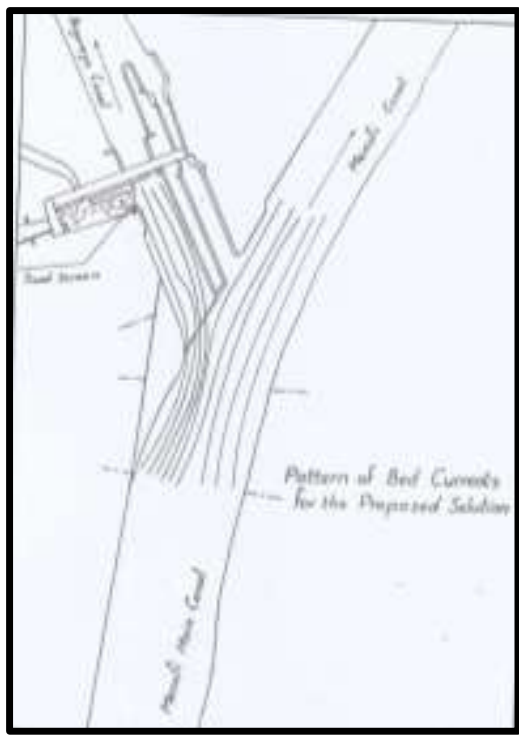

Figure 3

Illustrative drawing showing the connection of the Minoufi main canal with the Bagouria canal (The Ministry of Public Works)

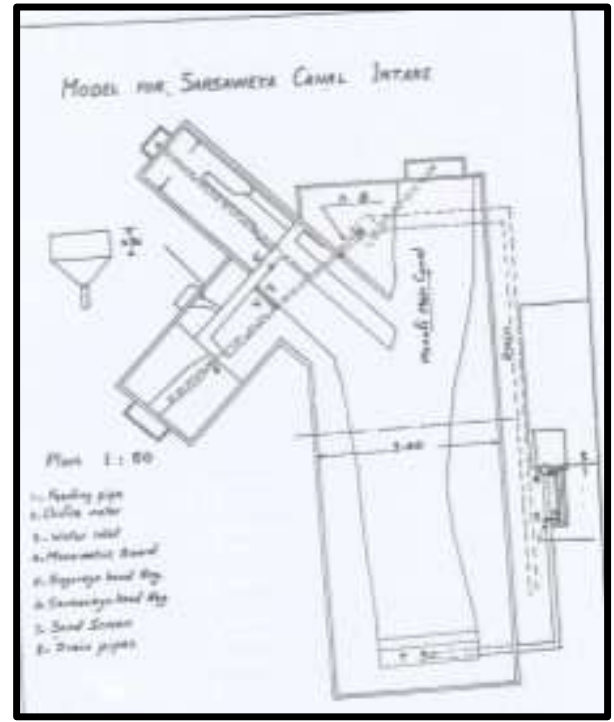

Figure 4

Illustrative drawing showing the level of water and silt at the connection of the Minoufi Main Canal with both the Bagouria and the Sarsawia Canals.

(The Ministry of Public Works)

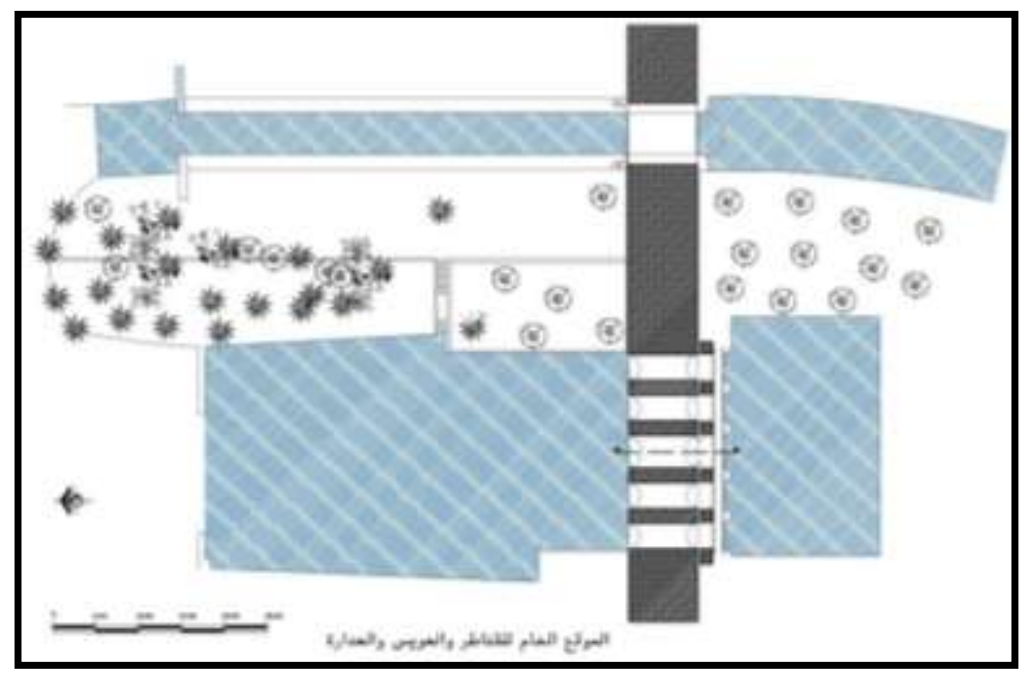

\section{Figure 5}

Horizontal plan showing the layout of the barrage, lock and weir of the Bagouria canal.

(Work of the researcher) 


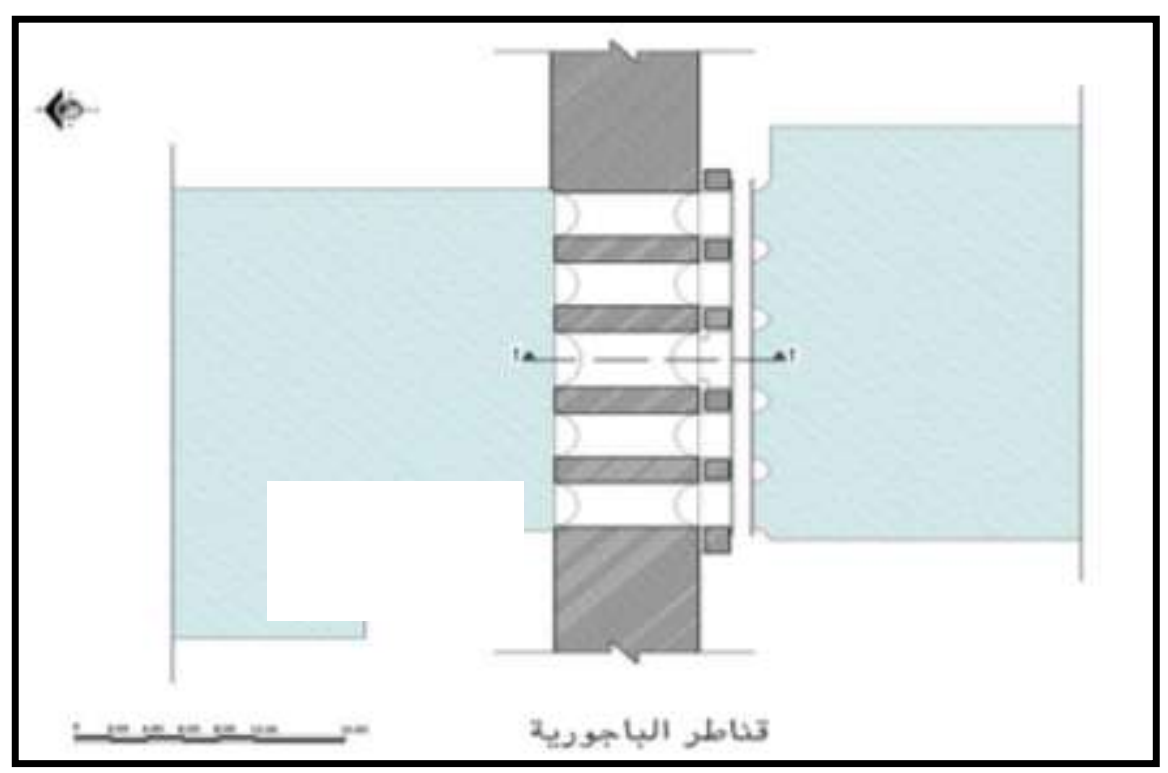

Figure 6

Horizontal plan showing the layout of the Bagouria barrage.

(Work of the researcher)

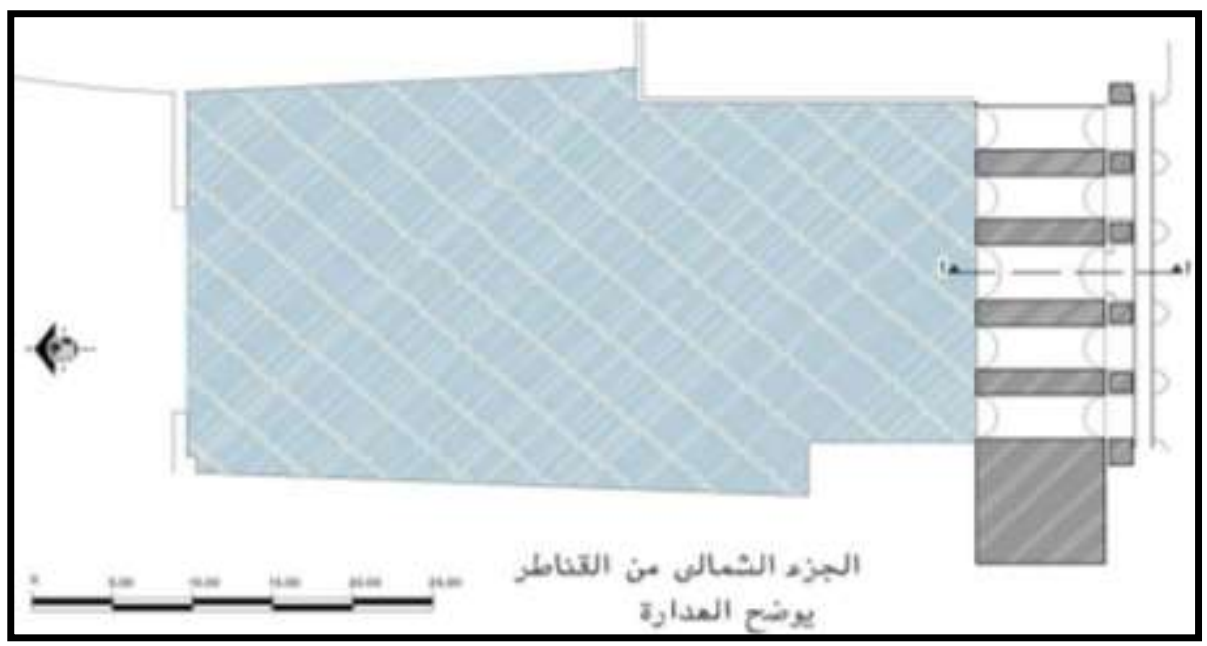

Figure 7

Horizontal plan showing the layout of the barrage and the weir of the Bagouria. (Work of the researcher) 


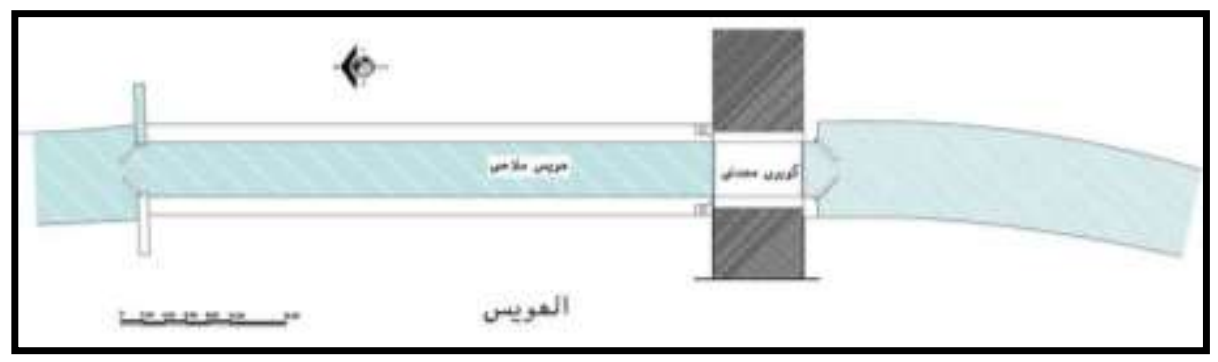

\section{Figure 8}

Horizontal plan showing the layout of the Bagouria lock.

(Work of the researcher)

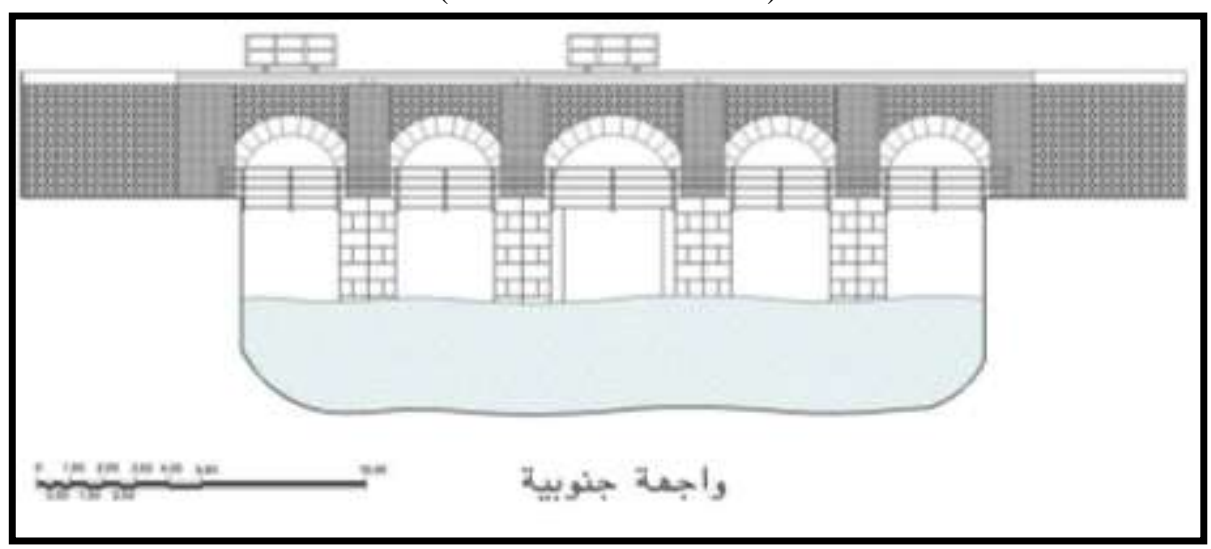

Figure 9

Horizontal plan showing the front façade of the Bagouria barrage.

(Work of the researcher)

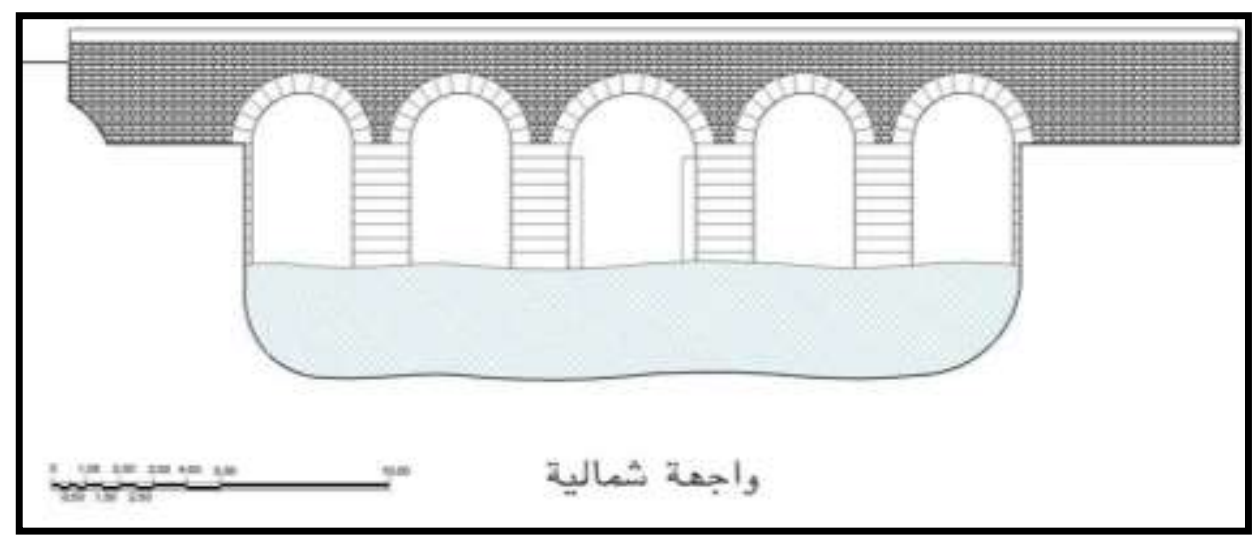

Figure 10

Horizontal plan showing the back façade of the Bagouria barrage.

(Work of the researcher) 


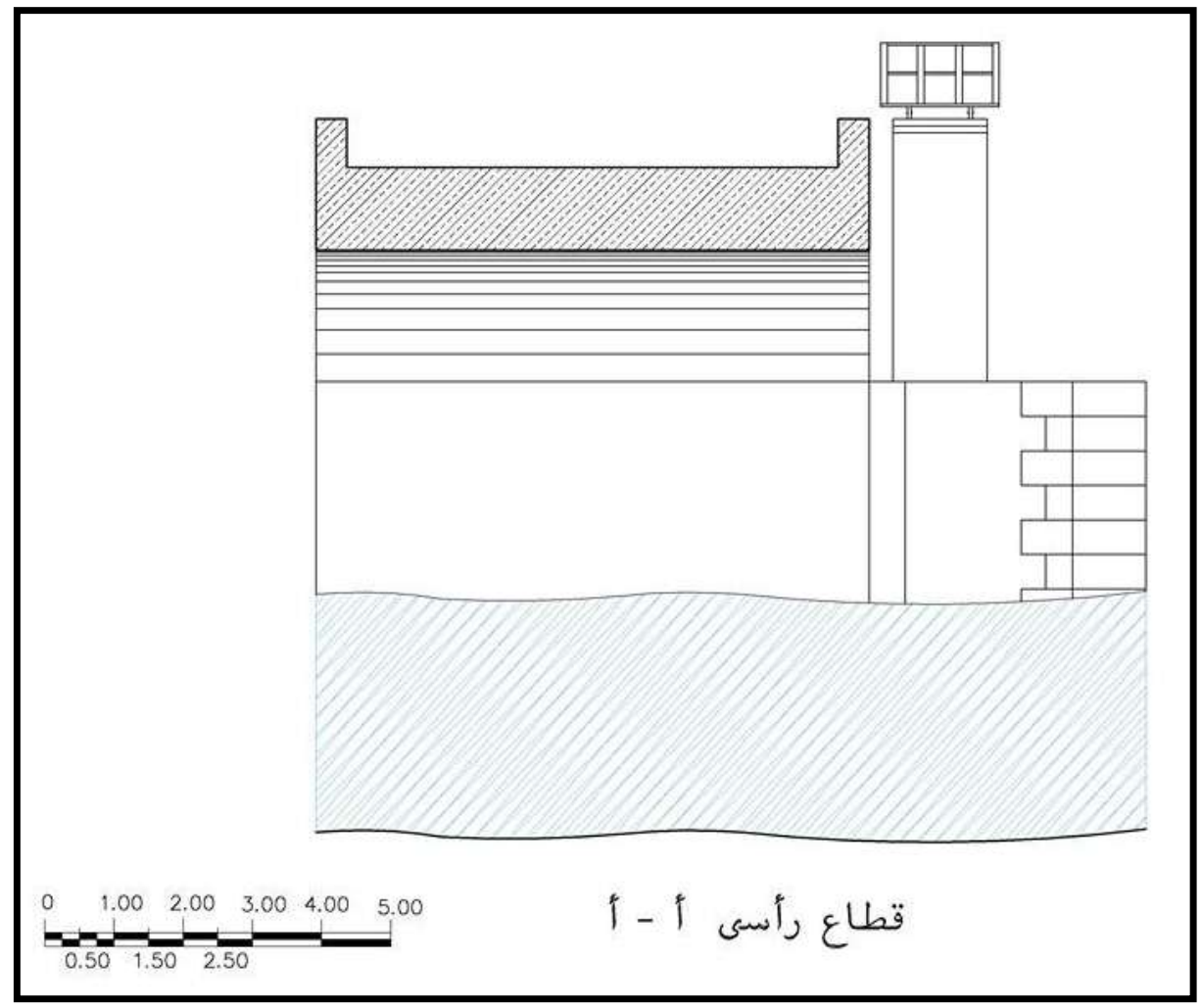

\section{Figure 11}

A vertical sector showing the Bagouria barrage.

(Work of the researcher) 


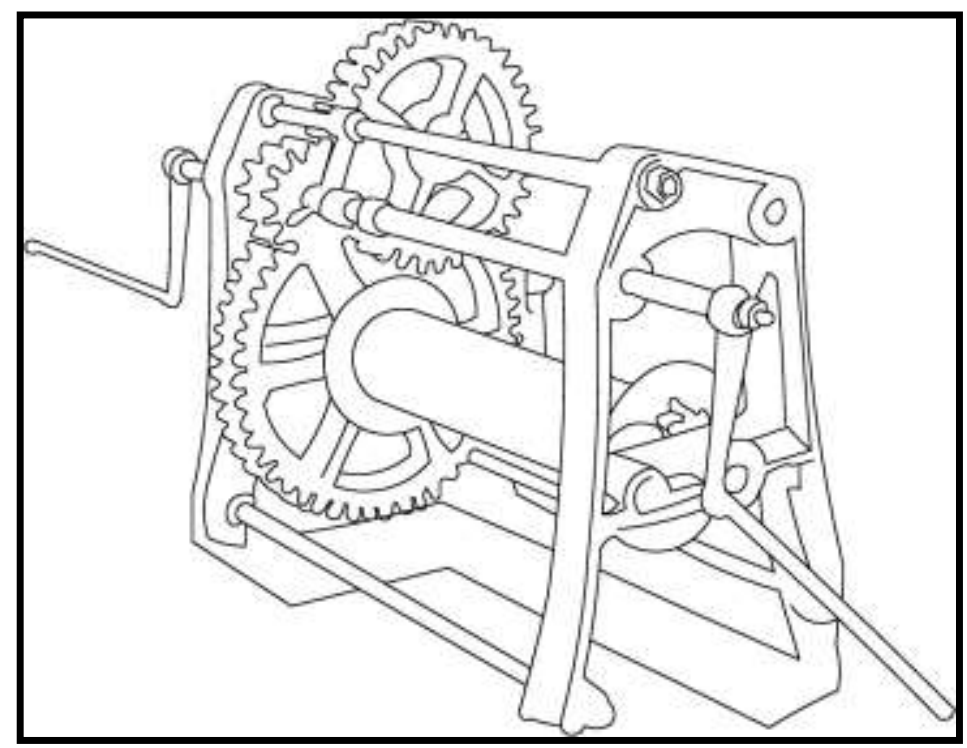

Figure 12

The Crane used in the Bagouria lock.

(Work of the researcher)

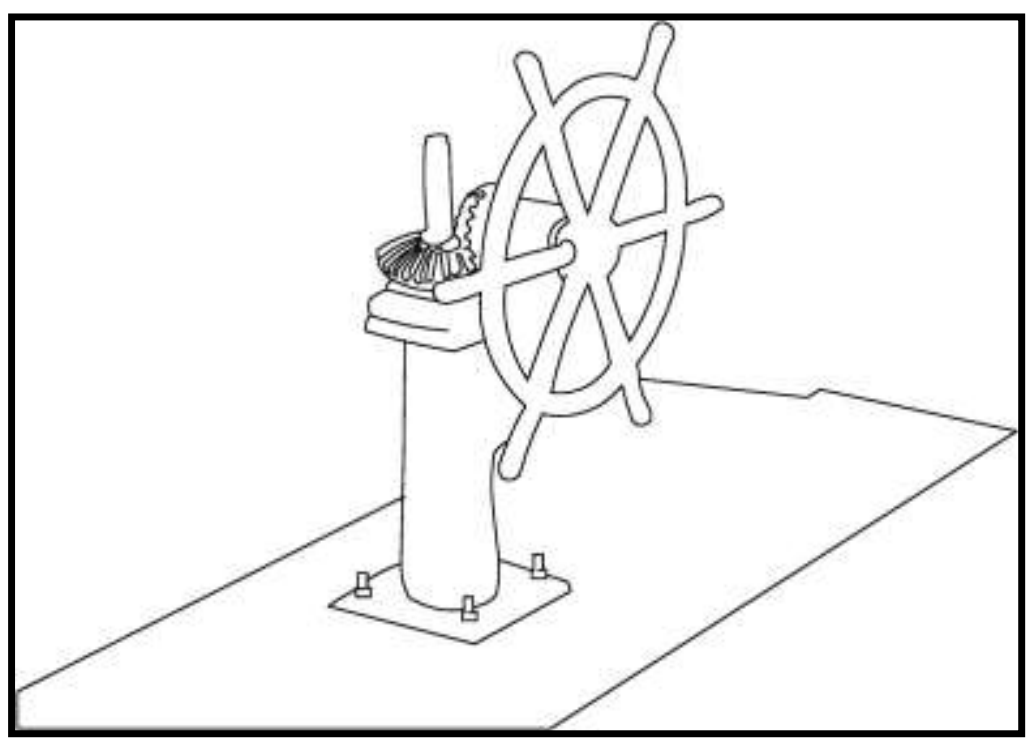

Figure 13

The manual tool used in the Bagouria lock.

(Work of the researcher) 


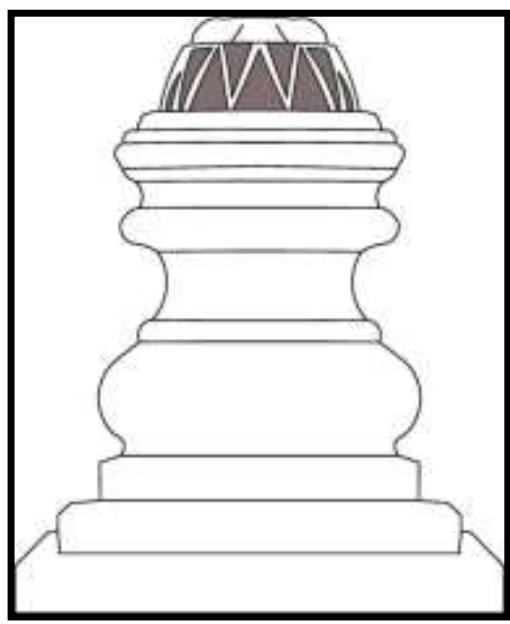

Figure 14

The shape of stone moulding that decorates the Bagouria barrage.

(Work of the researcher)

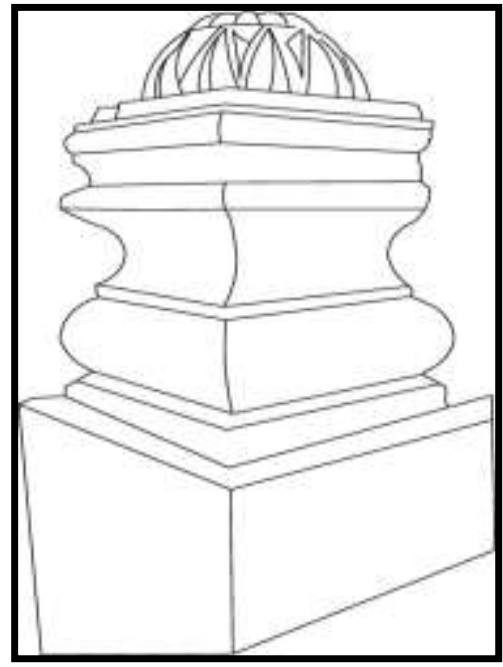

Figure 16

The shape of stone moulding that decorates the Bagouria barrage.

(Work of the researcher)

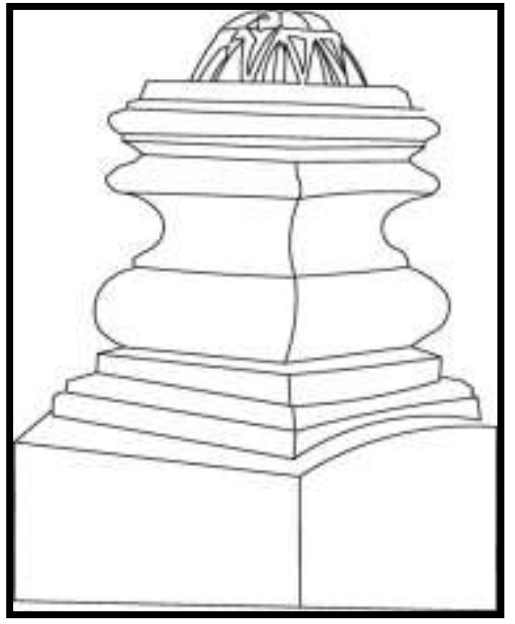

Figure 15

The shape of stone moulding that decorates the Bagouria barrage.

(Work of the researcher)

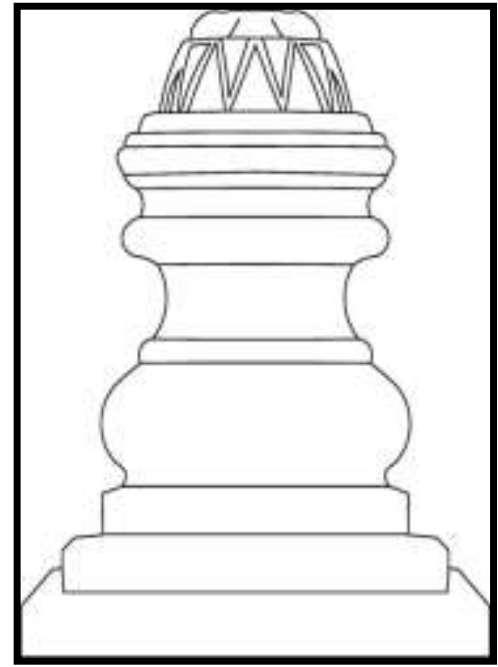

Figure 17

The shape of stone moulding that decorates the Bagouria barrage.

(Work of the researcher) 


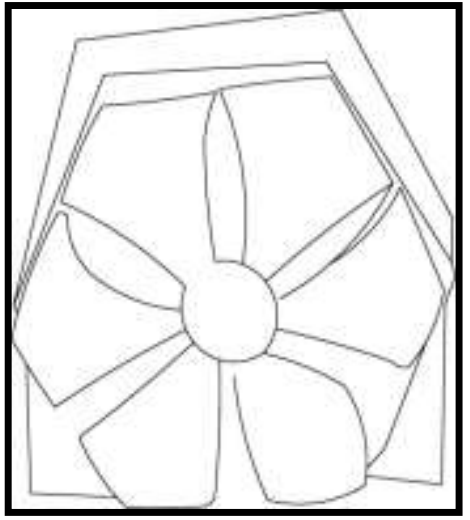

Figure 18

The decorations of stone moulding that adorn the

Bagouria barrage.

(Work of the researcher)

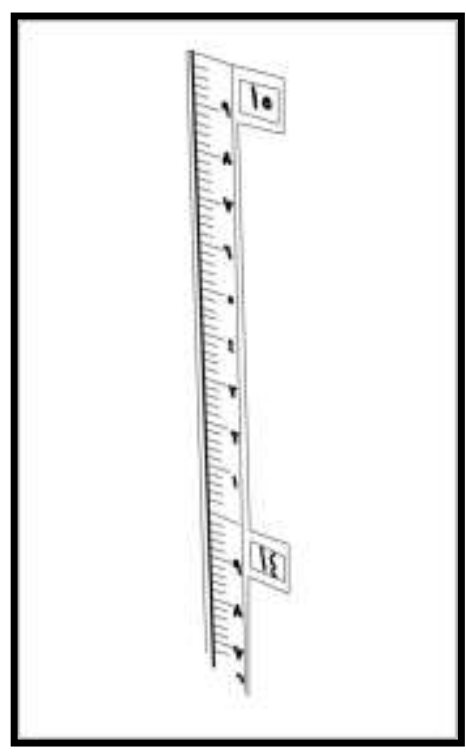

Figure 20

Showing the form of one of the Nilometers in the Bagouria barrage. (Work of the researcher)

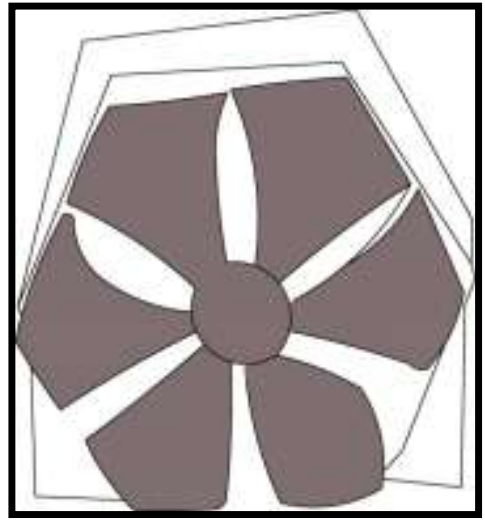

Figure 19

The decorations of stone moulding that adorn the Bagouria barrage.

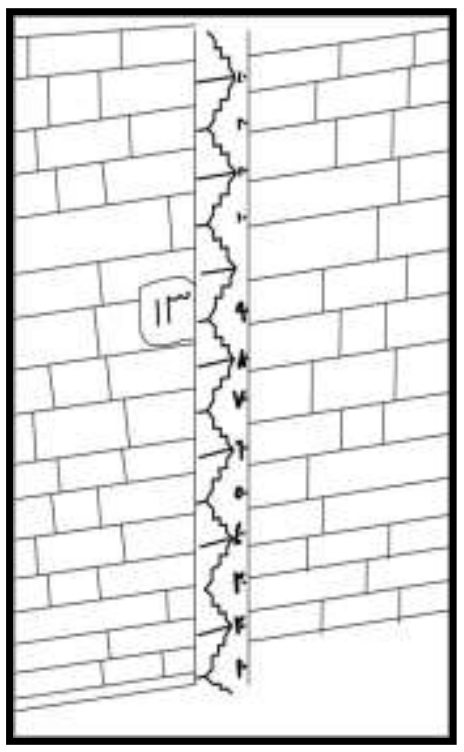

Figure 21

Showing the form of one of the Nilometers in the Bagouria barrage. (Work of the researcher) 


\section{Second: Plates:-}

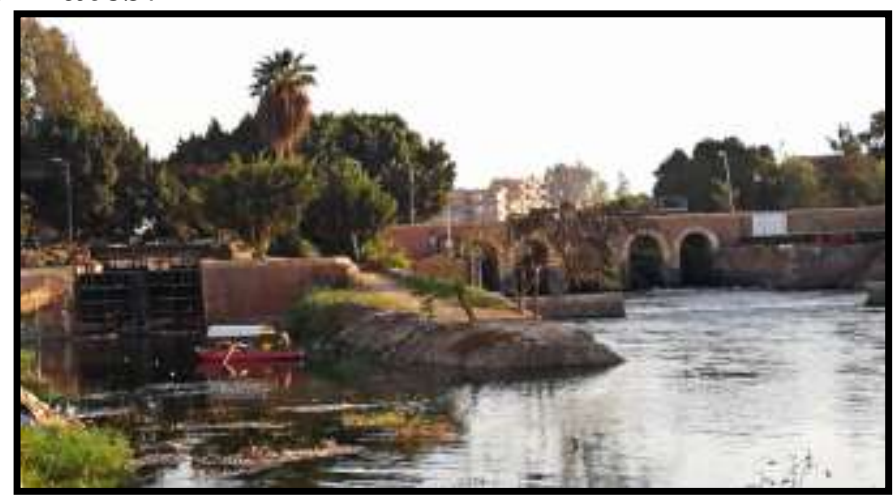

Plate No. 1: General view showing the barrage and the lock of the Bagouria (Photographed by the researcher).

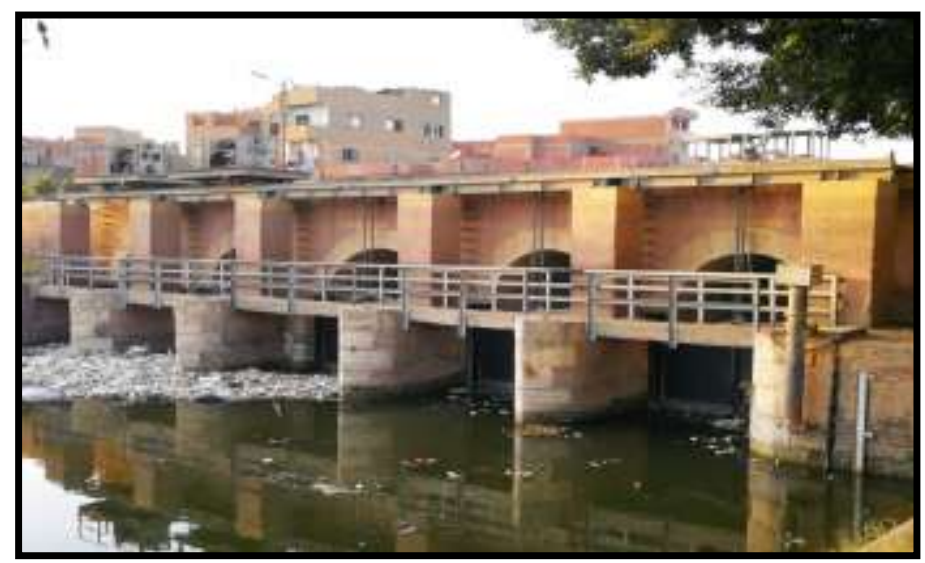

Plate No. 2: General view showing the front façade of the Bagouria barrage (Photographed by the researcher).

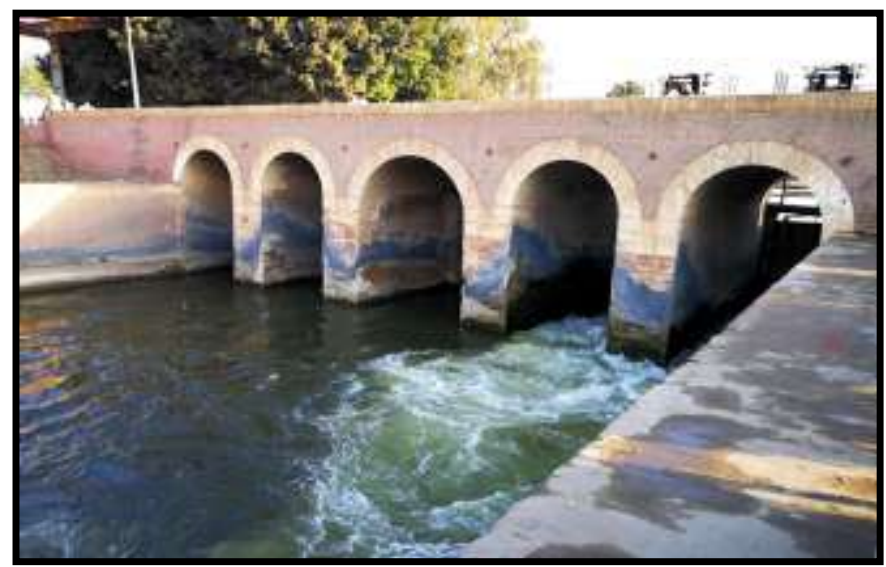

Plate No. 3: The back façade with semi-circular arches of the Bagouria barrage (Photographechby the researcher). 


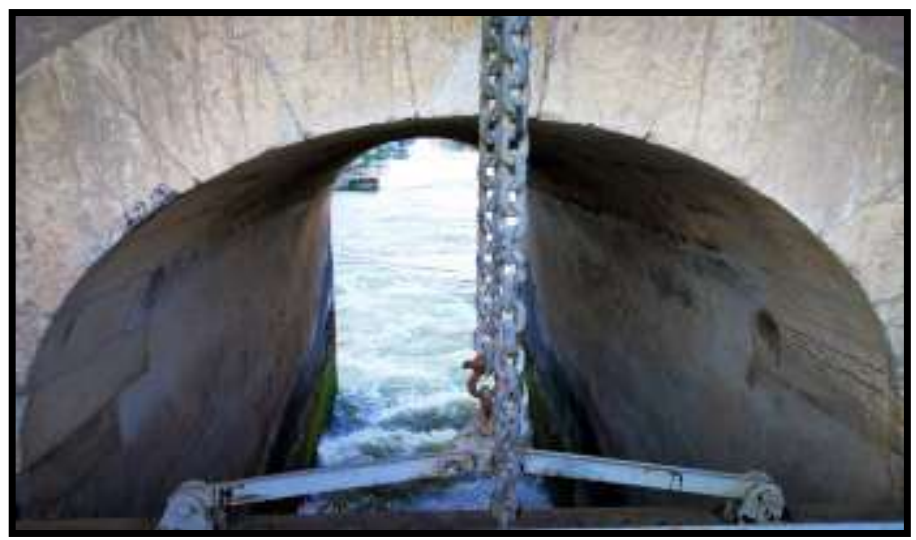

Plate No. 4: Tracked steel chains that carry iron gates for closing the openings of the barrage (Photographed by the researcher).

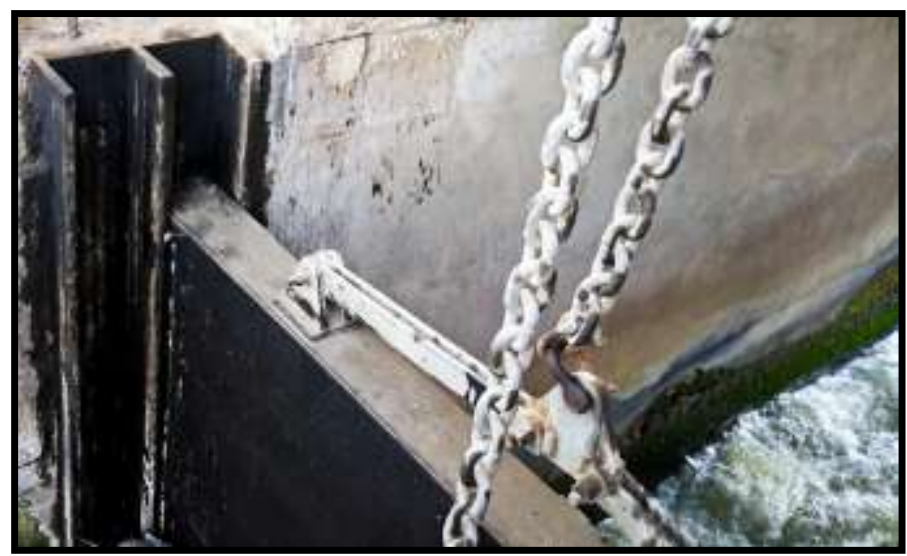

Plate No. 5: Recesses for the installation of iron gates of the Bagouria barrage. (Photographed by the researcher)

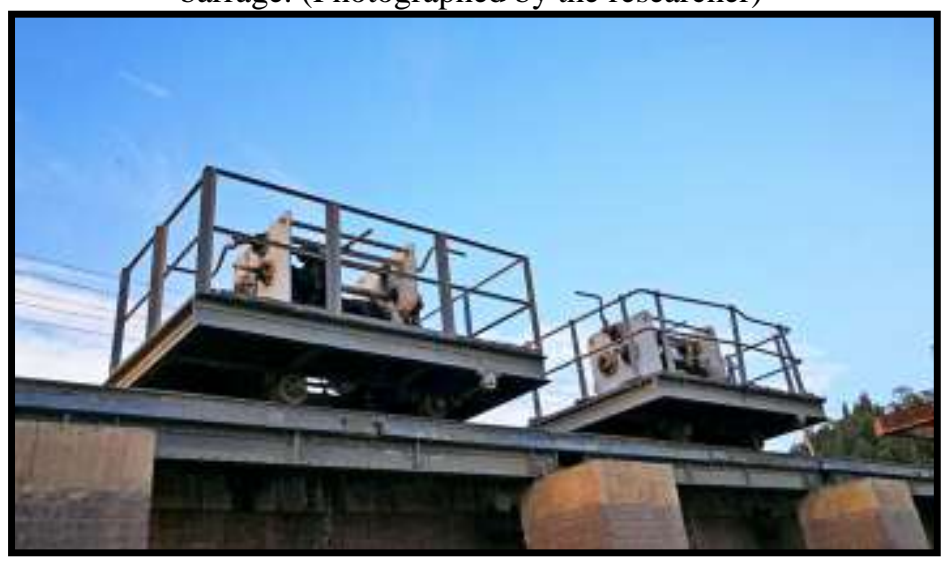

Plate No. 6: The cranes of the Bagouria barrage (Photographed by the researcher) 


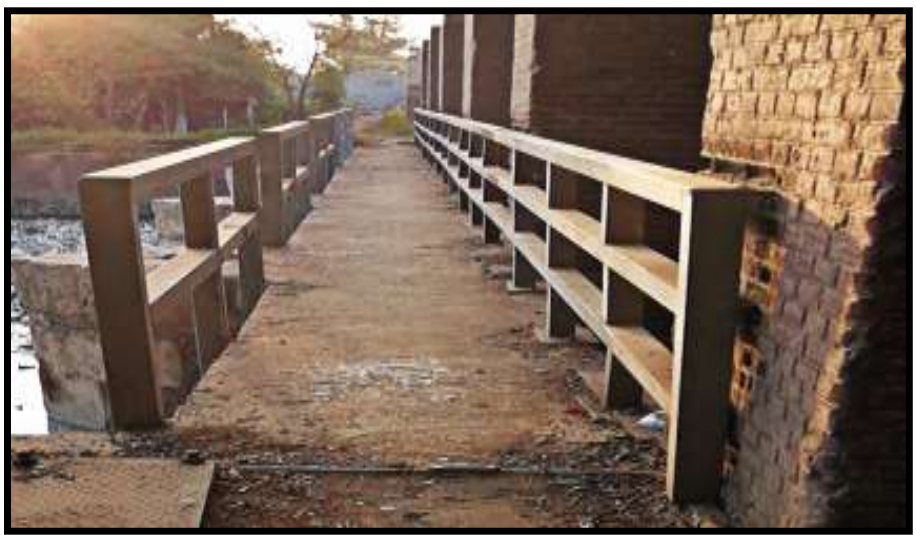

Plate No. 7: Viaduct with an iron balustrade adjacent to the front façade of the Bagouria barrage (Photographed by the researcher).

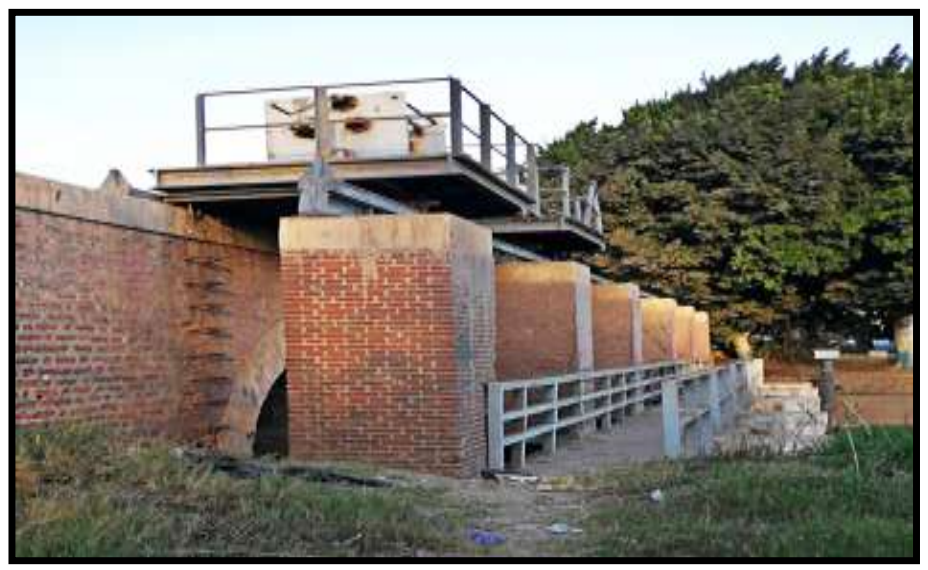

Plate No. 8: Viaduct and the shoulders located on the front façade of the Bagouria barrage (Photographed by the researcher).

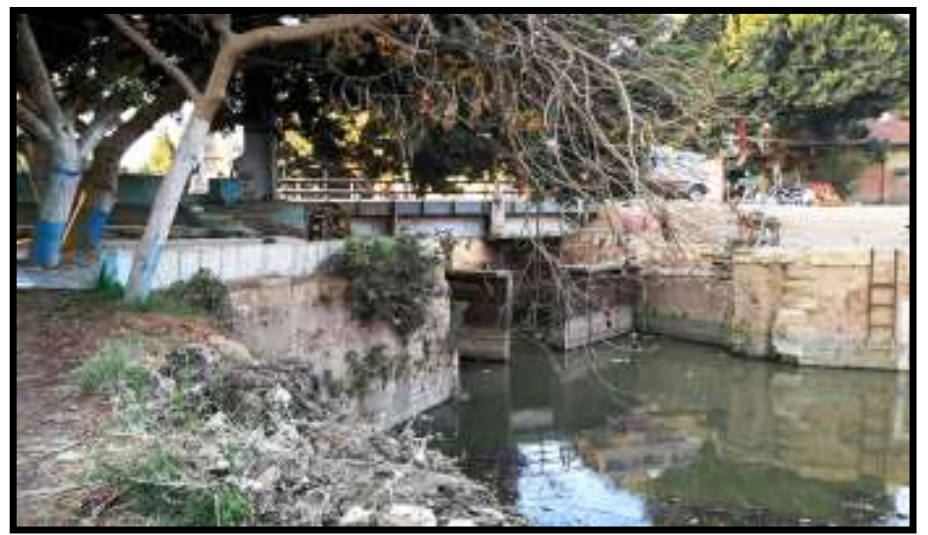

Plate No. 9: The front side of the Bagouria lock.

(Photographed by the researcher) 


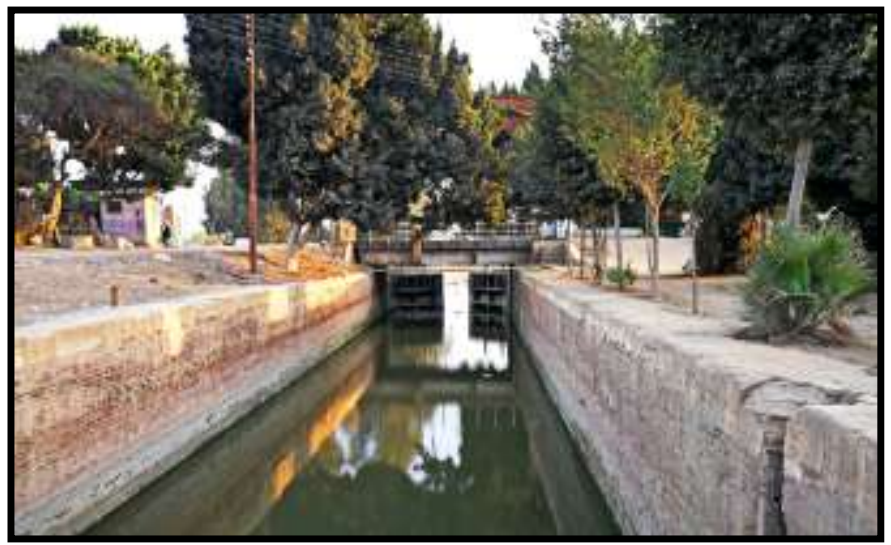

Plate No. 10: The back side of the Bagouria lock.

(Photographed by the researcher)

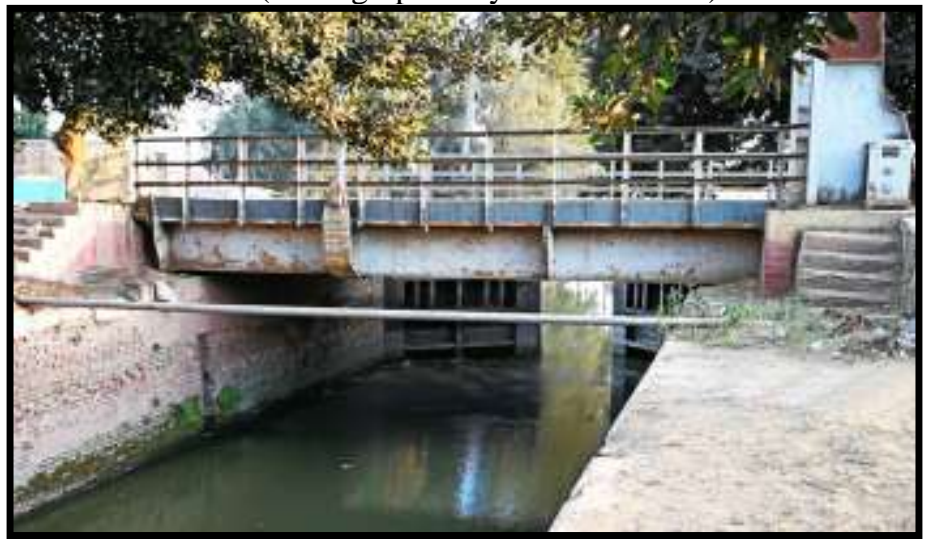

Plate No. 11: the bridge of the Bagouria lock (Photographed by the researcher)

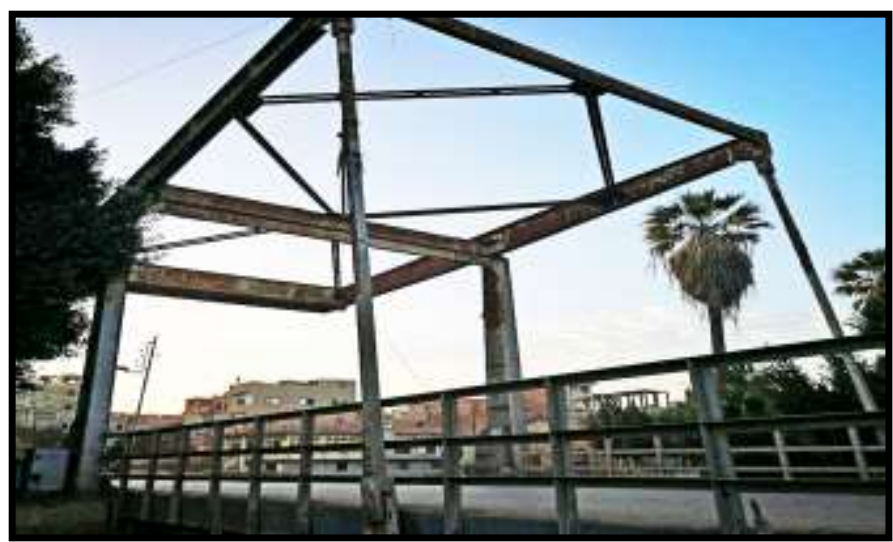

Plate No. 12: The upper part of the Bridge of the Bagouria lock. (Photographed by the researcher) 


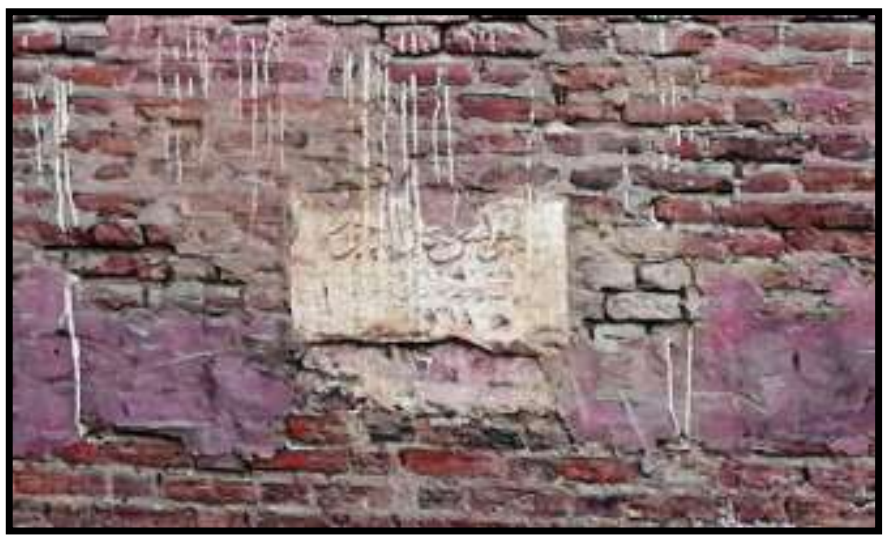

Plate No. 13: Marble stela with the renovation date of the Bagouria lock in 1911 (Photographed by the researcher).

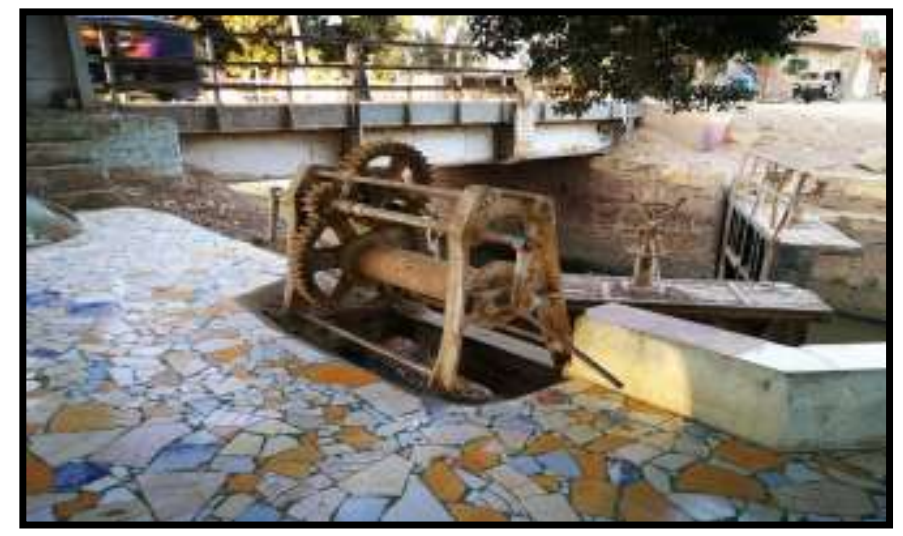

Plate No.14: Manual tools used in the Bagouria Lock.

(Photographed by the Researcher)

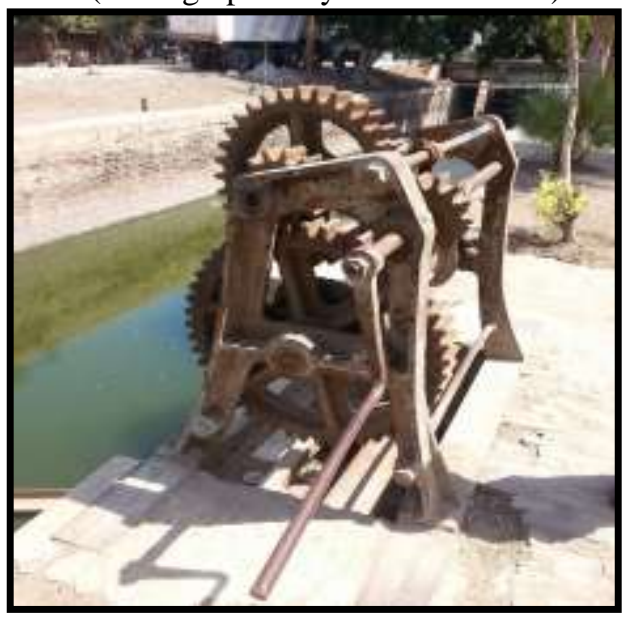

Plate No. 15: The crane used in Bagouria Lock.

(Photographed by the researcher) 


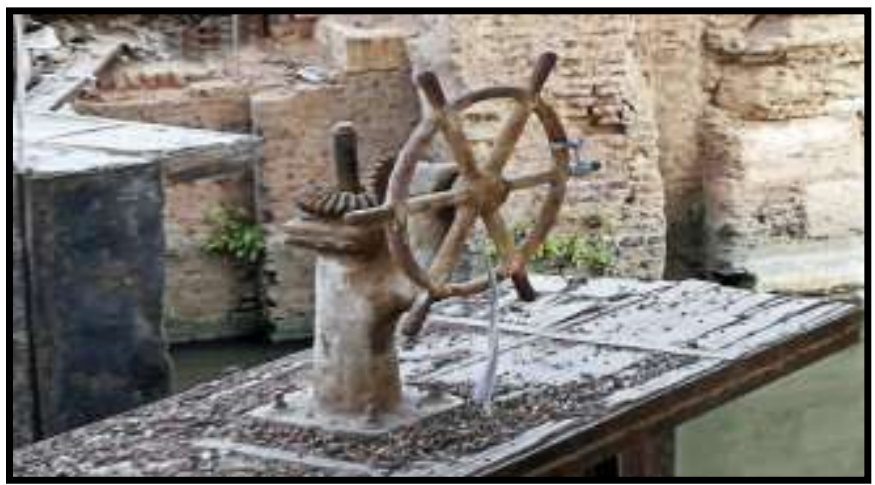

Plate No. 16: Manual tool used in the Bagouria Lock. (Photographed by the researcher)

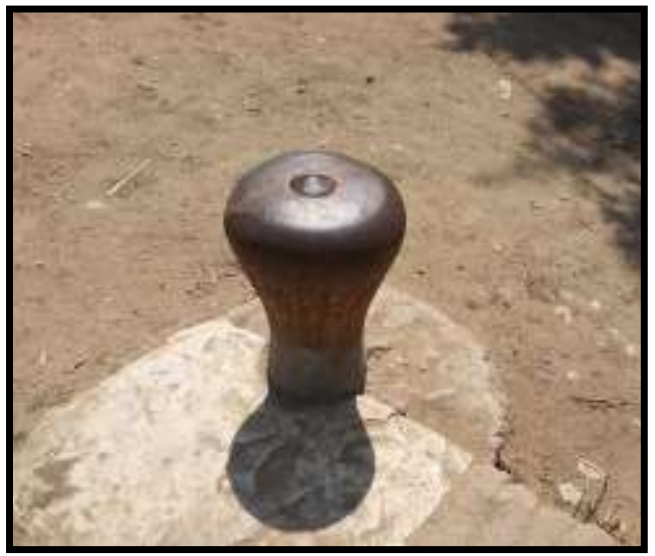

Plate No. 17: A metal peg used to tie the ropes of boats and ships at the Bagouria Lock. (Photographed by the researcher)

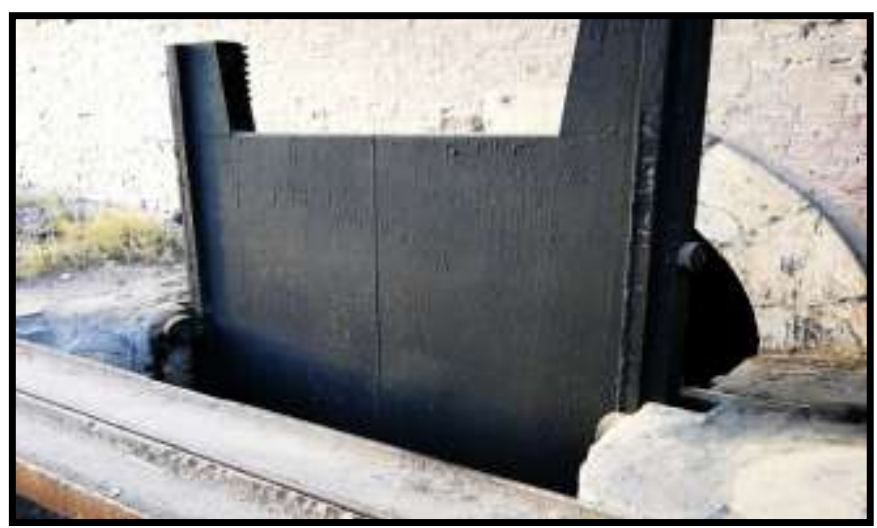

Plate No. 18: The barrage of Bai Arab.

(Photographed by the researcher) 


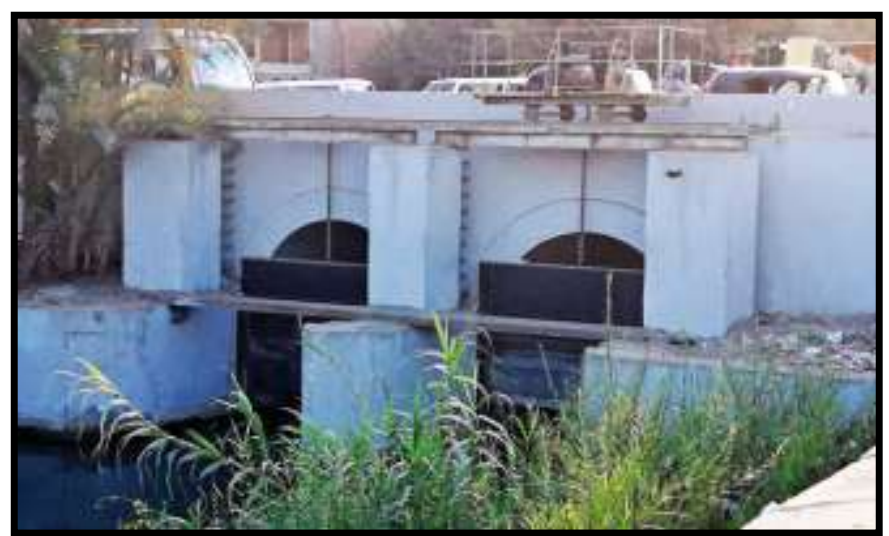

Plate 19: A general view showing the eastern front façade of the Sersawya barrage (photographed by the researcher)

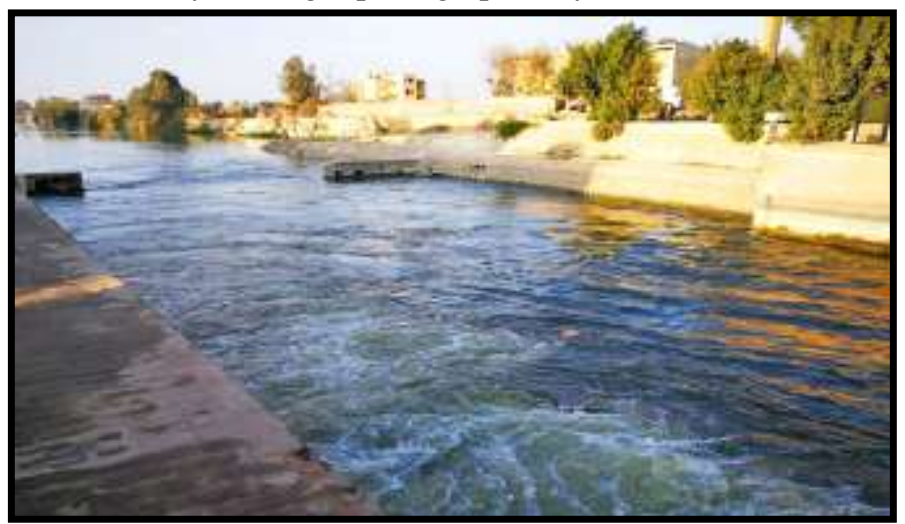

Plate No. 20: The weir of the Bagouria barrage.

(Photographed by the researcher)

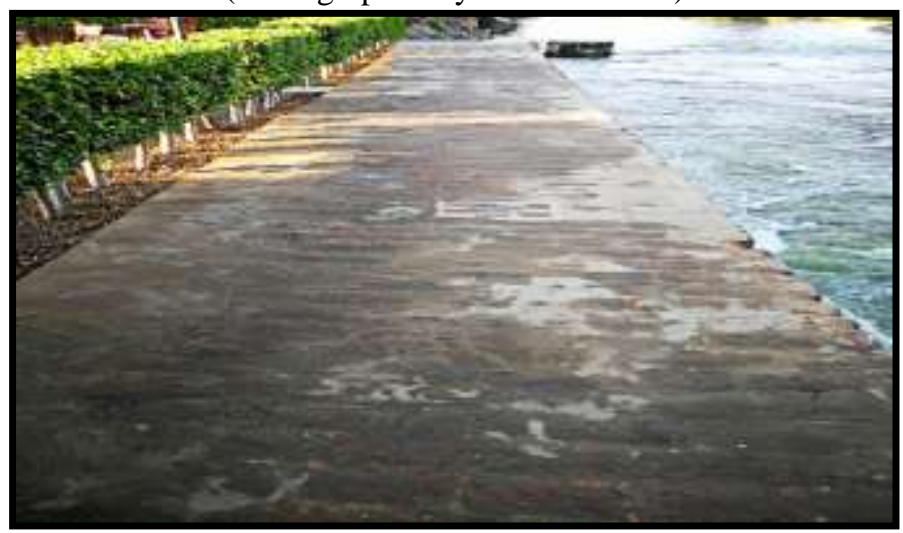

Plate No. 21: The western pavement of the weir of the

Bagouria barrage. (Photographed by the researcher) 


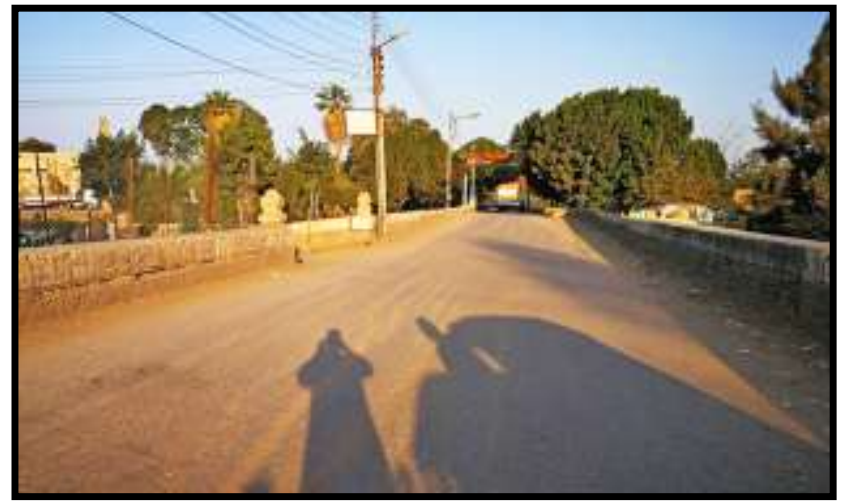

Plate No. 22: The upper road of the Bagouria barrage. (Photographed by the researcher)

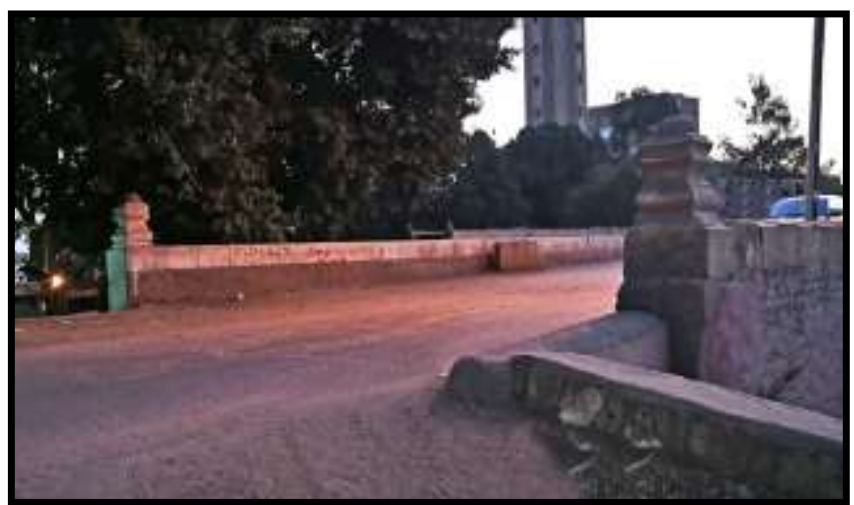

Plate No. 23: The eastern entrance of the upper road of the Bagouria barrage (Photographed by the researcher).

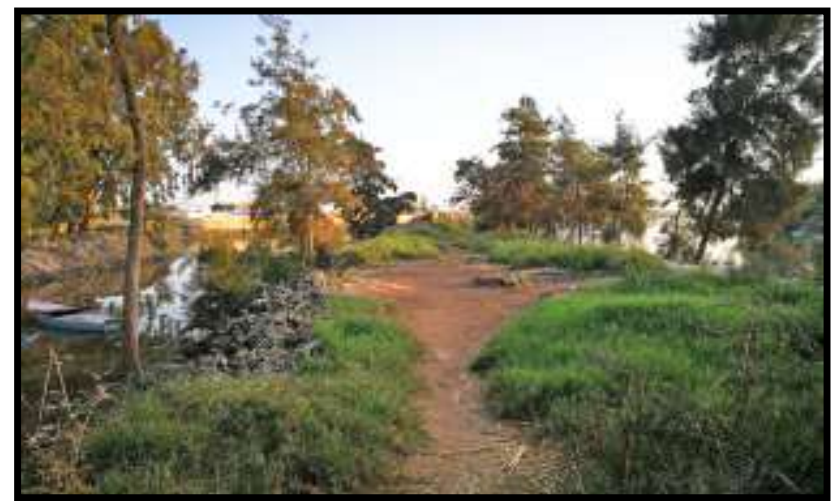

Plate No. 24: The embankment between the front entrance of the barrage and lock of the Bagouria canal (Photographed by the researcher) 


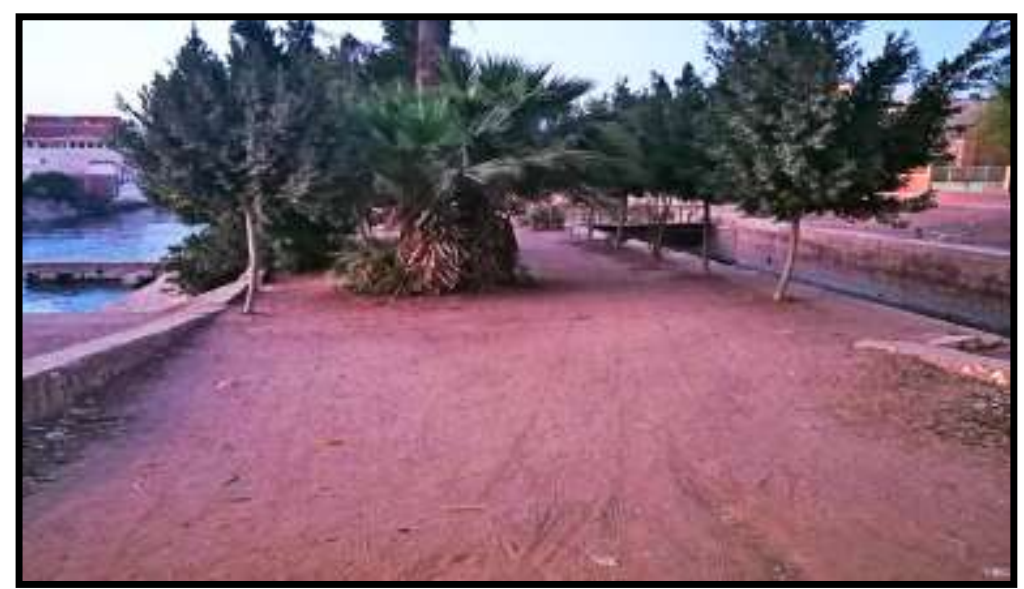

Plate No. 25: The embankment between the weir and the lock from the back side (Photographed by the researcher).

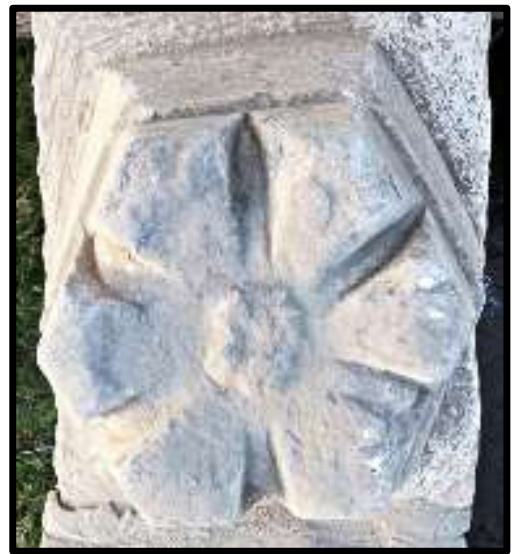

Plate No. 26: A decorative stone moulding adorning the Bagouria barrage (Photographed by the researcher)

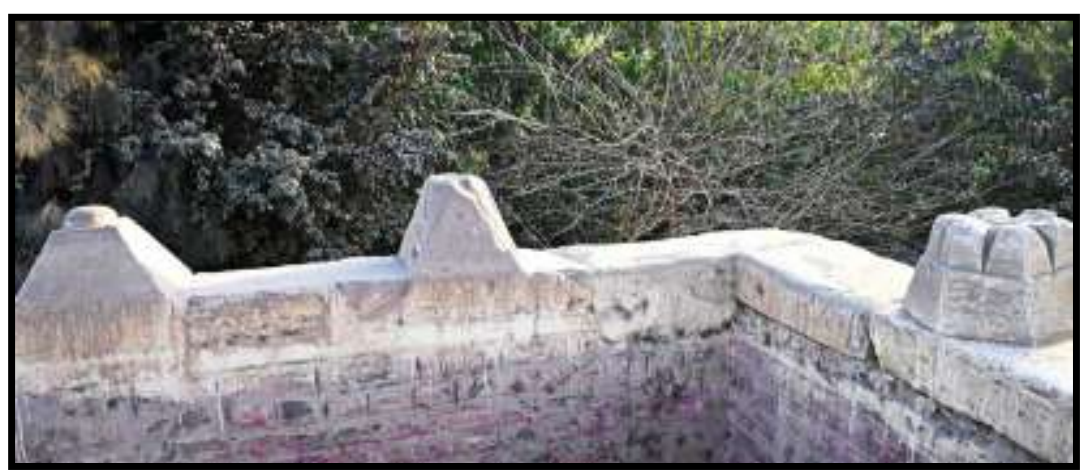

Plate No. 27: A group of decorative stone mouldings adorning the Bagouria barrage (Photographed by the researcher). 


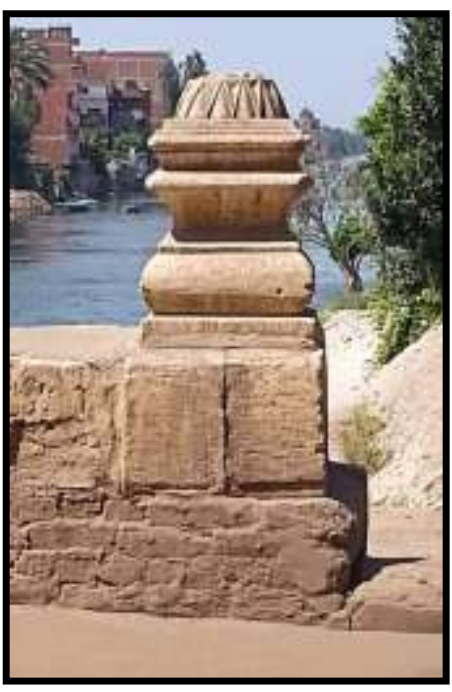

Plate No. 28: A decorative stone moulding adorning the Bagouria barrage (Photographed by the researcher).

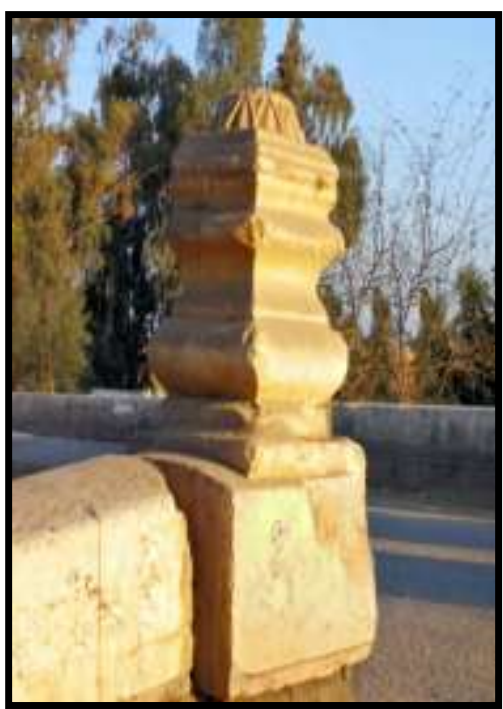

Plate No. 30: A decorative stone moulding adorning the Bagouria barrage

(Photographed by the researcher)

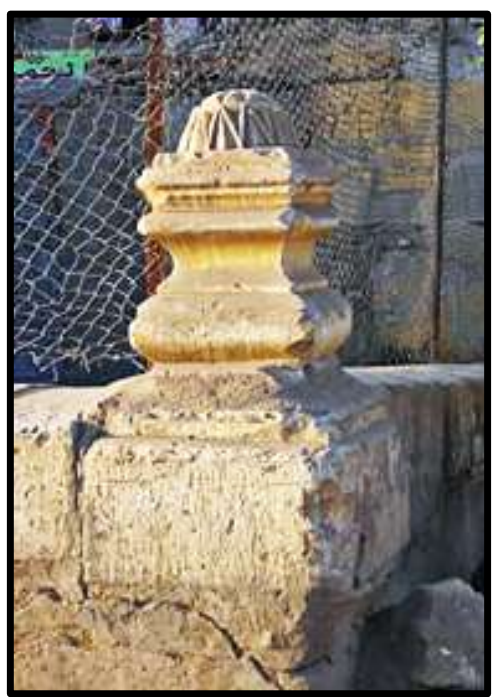

Plate No. 29: A decorative stone moulding adorning the Bagouria barrage

(Photographed by the researcher).

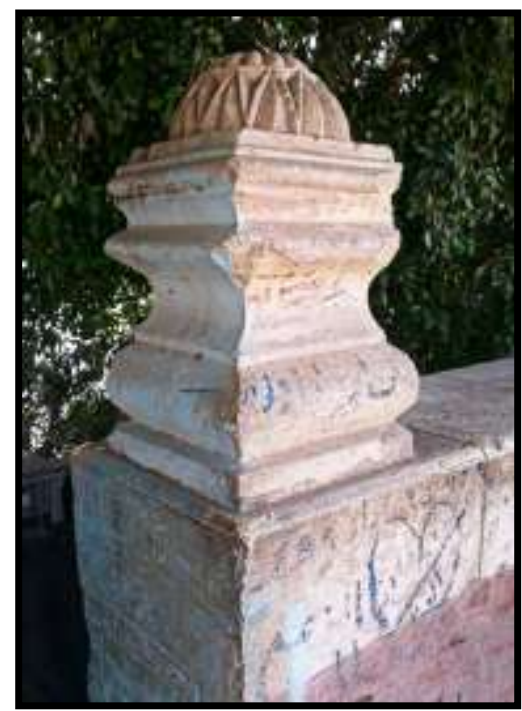

Plate No. 31: A decorative stone moulding adorning the Bagouria barrage

(Photographed by the researcher) 


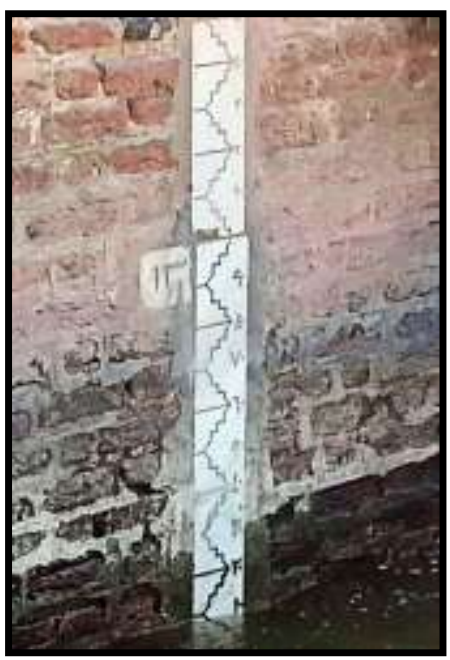

Plate No. 32: One of the Nilometers located at the wall of the pavement between the lock and the Bagouria barrage.

(Photographed by the researcher)

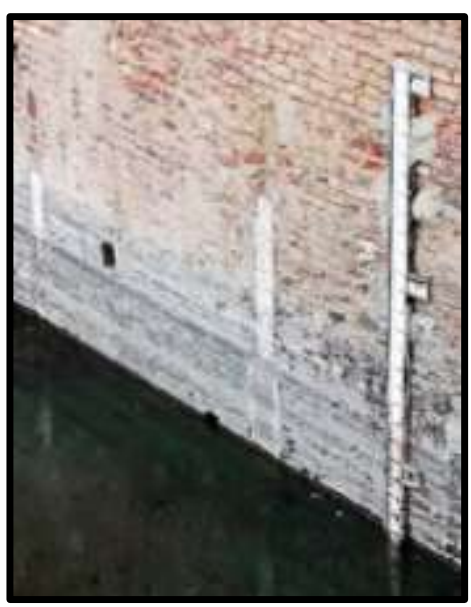

Plate No. 34: Three Nilometers located at the eastern wall behind the lock of the Bagouria barrage (Photographed by the researcher)

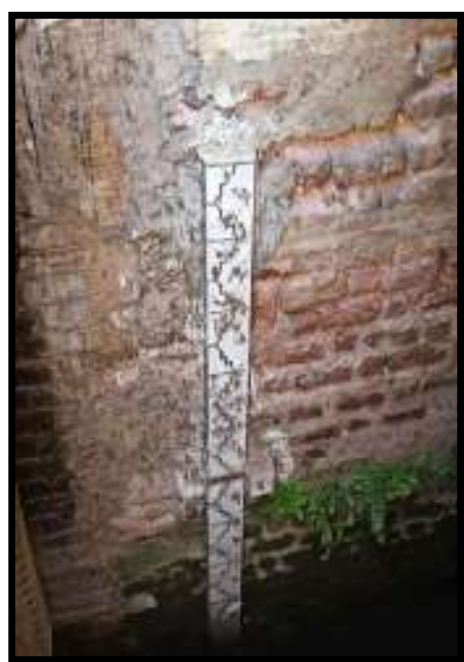

Plate No. 33: The Nilometer located at the entrance of the Sarsawiya barrage (Photographed by the researcher)

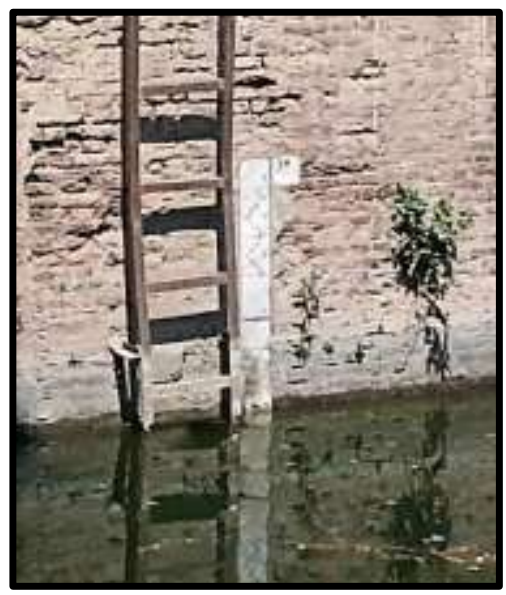

Plate No. 35: A Nilometer located at the eastern wall in front of the lock of the Bagouria

(Photographed by the researcher) 


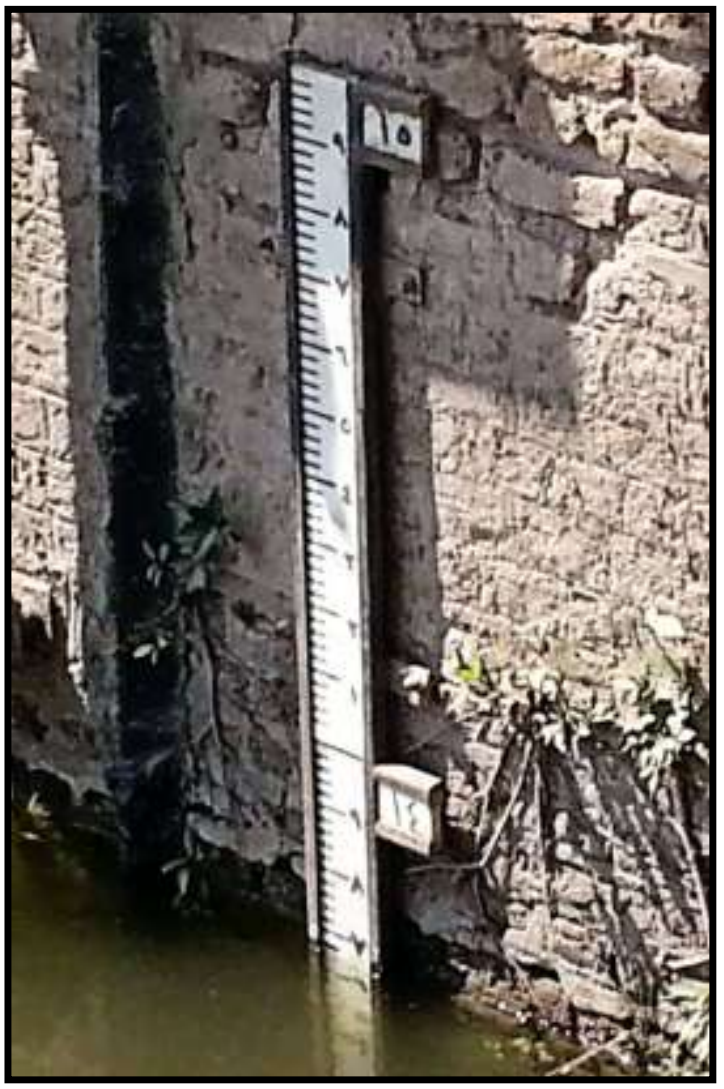

Plate No. 36: A Nilometer located at the eastern side of the front façade of the Bagouria barrage (Photographed by the researcher) 


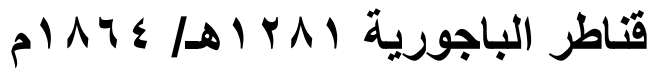 \\ (در اسة آثارية معمارية)}

\section{د. بلر عبد العزيز محمد بلرن}

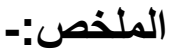

ينتاول هذا البحث بالدراسة والوصف والتحليل قناطر الباجورية، وتعد هن أهم

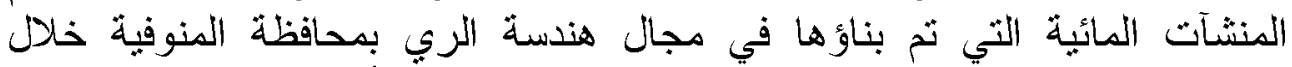

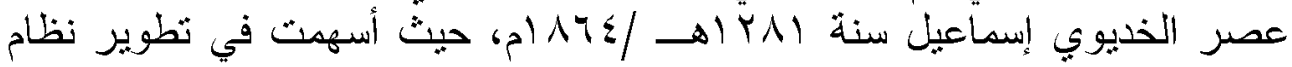

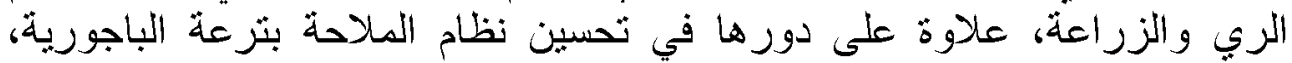

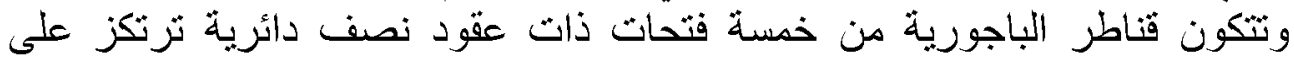

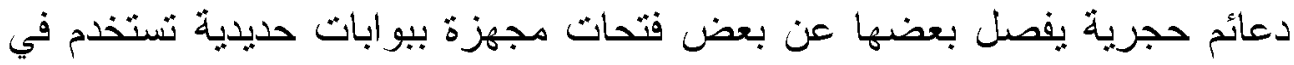

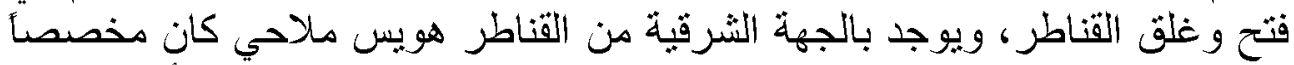

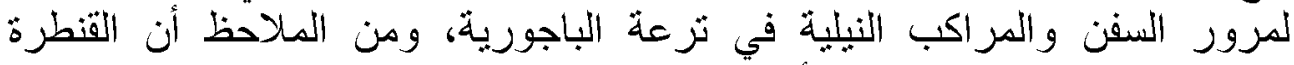

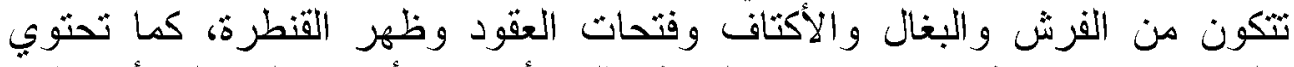

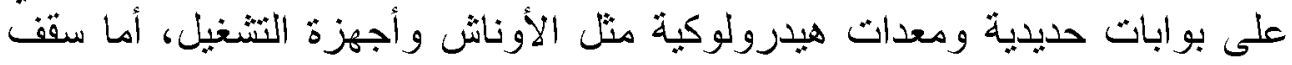

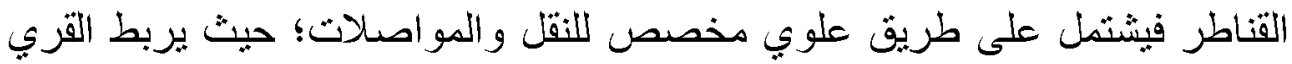

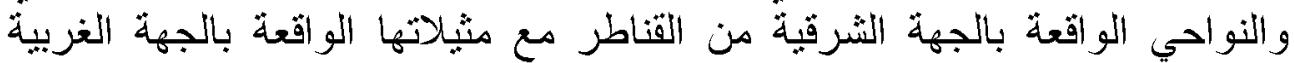

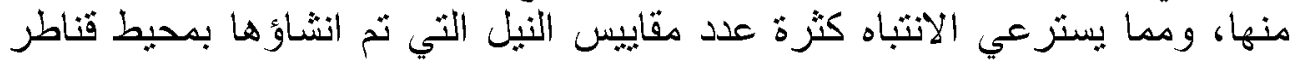

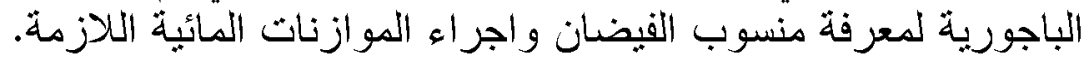
وفى نهاية البحث أهم النتائج التي تم التوصل إليها يليها قائمة المصادر و المراجع ثماثم

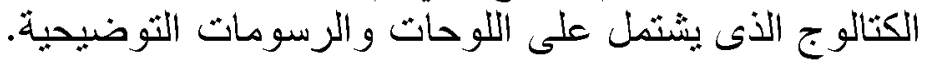

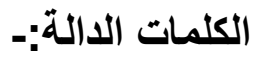

قناطر الباجورية؛ الهويس؛ البغال؛ الفرش؛ الهدار؛ البوابات الحديدية؛ الأوناش؛ المز اليج؛ مقاييس النيل. تورئ.

• أستاذ مساعد بكلية الآداب - جامعة بورسعيد. Szabadr@yahoo.com 